\title{
From natural forest to cultivated land: Lichen species diversity along land-use gradients in Kanchenjunga, Eastern Nepal
}

\section{Til Bikram Chongbang, Christine Keller, Michael Nobis, Christoph Scheidegger \& Chitra Bahadur Baniya}

Keywords: canopy openness, Canonical Correspondence Analysis, Ghunsa valley, hemispherical photography, land-use change, lichen diversity

\section{Abstract}

Profile

This study aimed to evaluate the effects of elevation, land use and canopy openness on species richness and composition of lichens in Ghunsa valley of Kanchenjunga Conservation Area, Eastern Nepal. At five elevational levels, from 2200 m to $3800 \mathrm{~m}$, transects were established in four land-use types - cultivated land, meadows, exploited and natural forests. Detrended Correspondence Analysis (DCA) and Canonical Correspondence Analysis techniques were used to explore the lichen species distribution patterns. Generalized linear models were applied to analyse the impact of elevation and canopy openness on lichen species richness. Canopy openness was measured by hemispherical photography. A total of 229 species belonging to 71 genera were recorded. The length of the first DCA axis of 8.01 SD units indicated a complete species turnover and high beta diversity along the elevation gradient. Exploited forests with lower canopy openness supported higher lichen diversity than open meadows and cultivated areas. Significant differences in lichen species richness were found for different land-use types, along the elevation gradient, and with varying canopy openness. A gradual increase of lichen species richness from cultivated land to forests was observed. We concluded that substrate types that depend on land-use types as well as canopy openness significantly affect the distribution of lichen communities.

Protected area

Kanchenjunga

Conservation Area

Mountain range

Himalaya

Country

Nepal

\section{Introduction}

Lichen diversity along elevational gradients has been analysed intensively in recent years (Bruun et al. 2006; Grytnes et al. 2006; Pinokiyo et al. 2008; Cobanoglu \& Sevgi 2009; Baniya et al. 2010; Rai et al. 2011; Baniya et al. 2012) as well as lichen diversity along land-use gradients (Bergamini et al. 2005; Motiejûnaitë \& Faùtynowicz 2005; Stofer et al. 2006; Wolseley et al. 2006; Giordani et al. 2010). Similarly, some recent studies are concerned with the influence of canopy openness on species richness, diversity and distribution of lichens ( $\mathrm{Li}$ et al. 2011; Marmor et al. 2012; Li et al. 2013b, 2013a). However, effects of landuse related canopy openness on species richness and composition of lichens have rarely been studied.

Land-use change determines vegetation cover, species composition and distribution patterns of plant communities (Tasser \& Tappeiner 2002) and, consequently, the variation in key characteristics of host tree species, like their density, age and diameter, which all influence the composition and distribution of epiphytic lichen communities (Löbel et al. 2006; Mežaka et al. 2008; Cobanoglu \& Sevgi 2009; Li et al. 2011; Mežaka et al. 2012; Odor et al. 2013). Land-use changes, habitat loss and degradation often decline lichen populations (Scheidegger \& Werth 2009). Compared with other factors, changing light and moisture conditions are often the dominant factors to explain differences in lichen diversity and abundance ( $\mathrm{Li}$ et al. 2013a).

Nepal is a mountainous country in the central Himalayas with an area of $147181 \mathrm{~km}^{2}$. It is situated between China in the north and India in the east, south and west. The elevation ranges from $60 \mathrm{~m}$ above sea level in Terai to $8848 \mathrm{~m}$ at Mt Everest, the highest peak in the world (Chaudhary 1998).

In Nepal, lichens are found in all climatic zones. However, floristic and ecological studies on lichens are largely missing. The latest physiographic data of Nepal showed $29 \%$ of the total land area covered by forests, $10 \%$ by shrubs and degraded forests and $21 \%$ by cultivated land (MFSC 2009). Land-use and land-cover change are substantial in Nepal; especially the forest cover shows a drastic decline - even in protected areas. For the Kanchenjunga Conservation Area (KCA), for instance, Gautam and Watanabe (2004) found a decline in forest land cover by $14.9 \%$ and grazing land cover by $77.9 \%$ between 1979 and 1992 . This was the result of an increase in cultivated land by $4.9 \%$ and shrubland by $19.7 \%$. KCA is a community-managed protected area established in 1997 and handed over to the KCA Management Council by the government of Nepal in 2006. The shifting cultivation is a common traditional farming system practiced in this protected area by the local ethnic groups as their traditional oc- 


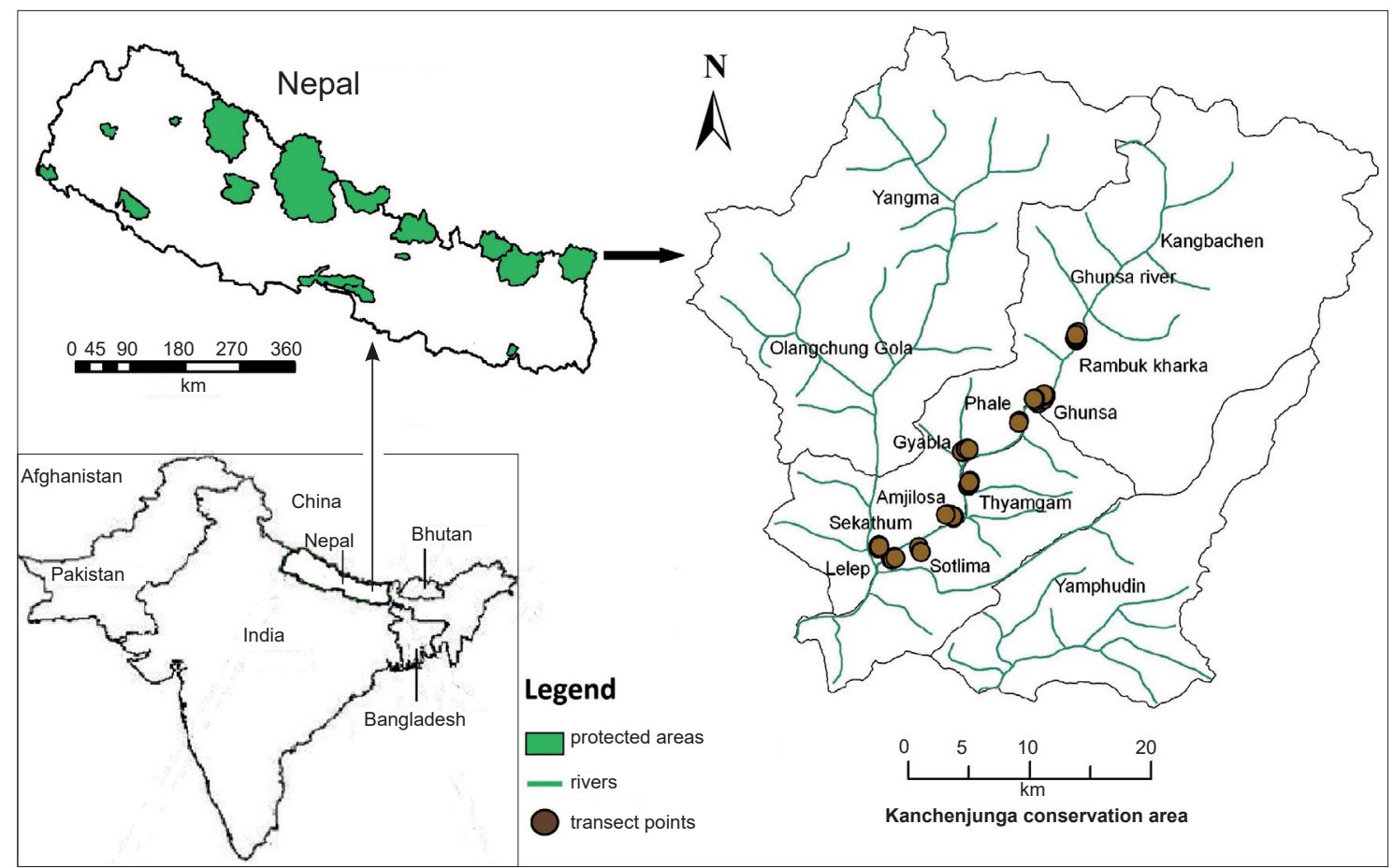

Figure 1-Map of the study area showing the locations of the study sites.

cupation and livelihood. It also falls within the Sacred Himalayan Landscape being developed by WWF Nepal (Aryal et al. 2010).

The main objective in the present study, therefore, is to evaluate the effects of different land-use types, canopy openness on species richness and composition of lichens along the elevational gradient in KCA, Eastern Nepal. We hypothesized that (a) lichen diversity generally decreases from forests to open land and (b) highest lichen diversity is reached in forests under intermediate canopy openness.

\section{Materials and methods}

\section{Study area}

This study was carried out in Ghunsa of Eastern Nepal between $2200 \mathrm{~m}$ and $3800 \mathrm{~m}$ (Figure 1). Ghunsa lies towards the north-eastern part of Nepal in the KCA. KCA is located between $27^{\circ} 24^{\prime}-27^{\circ} 57^{\prime} \mathrm{N}$ latitudes and $87^{\circ} 39^{\prime}-88^{\circ} 12^{\prime} \mathrm{E}$ longitudes, close to the boarders of China in the North and India in the East. KCA covers an area of $2035 \mathrm{~km}^{2}$ between the Middle Mountains and the high Himalayas, with an elevational range from $1200 \mathrm{~m}$ (Thiwa Khola) to Mt Kanchenjunga $(8586 \mathrm{~m})$, the third-highest peak in the world. The area includes three river valleys: Simbua, Ghunsa, and Tamur (Anonymous 2011). KCA has diverse climatic zones, including subtropical monsoon at $1200 \mathrm{~m}$ to alpine forests (above $4000 \mathrm{~m}$ ), where June to August are the warmest months, with monthly maximums of $24.73^{\circ} \mathrm{C}$ to $24.81^{\circ} \mathrm{C}$, and January is the coldest month, with a maximum temperature of $13.8^{\circ} \mathrm{C}$ (Shrestha \& Ghimire 1996). KCA receives a good amount of monsoon rainfall from April / May to September/Octo- ber, with a mean annual precipitation of $2013 \mathrm{~mm} / \mathrm{yr}$ (Anonymous 2009).

Field methods and data collection

Land-use types were classified according to land cover, disturbance frequency and intensity. At each elevational level, land-use gradients were stratified into four land-use types (Scheidegger et al. 2010).

1. Natural forest: Forested area with very little or no human disturbance. It includes mainly broad-leaved trees and pine trees. This land-use type is often several hours walking distance away from human settlements.

2. Exploited forest: Disturbed and / or exploited forests used for extensive grazing and / or the collection of fodder and firewood, which are close to human settlements.

3. Meadow: Areas dominated by grasses and scattered trees and shrubs. Grazed by domestic livestock like sheep, goats, buffaloes, cows, yaks, and horses.

4. Cultivated land: Land extensively used for cultivation and including terraced fields. These arable fields are often irrigated and fertilized.

Fieldwork was carried out in April 2012. Five elevation levels, from 2200-3800 m, with an interval of approximately $400 \mathrm{~m}$ were selected for the study. At each level, the four land-use types were selected on both sides of the Ghunsa river valley and two transects of $2.5 \mathrm{~m} \times 25 \mathrm{~m}$ each were studied at each land-use type on both sides of the valley, which showed southeast and north-west facing aspects. A total of 72 of 80 planned transects were established, because not all land-use types were found at each elevation level. The 
distance between two transects within the same landuse type was at least ten meters.

On each transect, elevation was recorded by Global Positioning System (Garmin, GPSmap60CSx) and slope, and the direction of the slope was recorded by a clinometer (Silva, Ranger). The growth form and substrate types were recorded. We considered the growth forms crustose, foliose, fruticose and leprose, and the substrate types corticolous (on bark), saxicolous (on rock), muscicolous (on moss) and terricolous (on soil) (Hale 1983). Hemispherical photographs were taken using a digital camera (Coolpix995 Nikon) and fish-eye lens (Fish-eye converter FC-E8 Nikon). The camera was mounted at a height of $1.5 \mathrm{~m}$ above the ground on a tripod and levelled with a bubble level.

Lichen identification and image analysis

Collected lichen specimens were examined at the Laboratory of the Central Department of Botany, Tribhuvan University, Kathmandu, Nepal, and at the Swiss Federal Research Institute, WSL, Switzerland. Identification of lichens was carried using the relevant keys and checklists (Awasthi 1991; Sharma 1995; Awasthi 2007; Singh \& Sinha 2010). Identified specimens were deposited at the Swiss Federal Research Institute WSL, Switzerland.

Lichen species were categorized according to family, growth forms, substrate type and photobiont types, i.e. cyanobacteria or green algae, following the recent updated taxonomical classification (Lücking et al. 2016). Data were organized in a relational database (MS Access). Hemispherical photographs were converted to binary (black and white pixels) following the image analysis manual described by Frazer et al. (1999). All image analyses were performed using image-processing software, Gap Light Analyzer (GLA Version 2.0).

\section{Statistical analysis}

We calculated Pearson correlation coefficients between variables such as total lichen species richness, growth forms, substrate types and photobiont types (i. e. green algal and cyanobacterial lichen species richness) and canopy openness. TukeyHSD multiple comparison tests were used to test the effect of particular land-use types on species richness of lichens. Generalized Linear Models (GLMs; McCullagh \& Nelder 1989) with quasi-poisson error distribution were performed for modelling lichen richness. We build models with linear only and linear and quadric predictor terms and chose the final model parameterization according to the significance of the quadratic term. Graphics were made only for statistically significant models by using GLM. GLMs were not built for species richness of leprose, terricolous and muscicolous lichens because of the scarcity of occurrence data.

Detrended Correspondence Analysis (DCA; Hill \& Gauch 1980) was used to determine the lengths of the main gradient in species composition based on the sample by species data matrix. We performed DCA with downweighting of rare species and found a gradient length 8.01 standard unit (SD) for the first axis. This indicated the use of Canonical Correspondence Analysis (CCA) (Lepš \& Šmilauer 2003) and its implied unimodal response model over a linear model like in Redundancy Analysis (RDA) to analyse the relationships between species co-occurrence and environmental variables (i.e., elevation, land-use type and canopy openness). All environmental variables were permuted 199 times during CCA to test for significant environmental variables. Direct correlations of environmental predictors with CCA axes were also performed.

All statistical analyses were performed using the vegan 2.4-0 package (Oksanen et al. 2016) under the free statistical software environment $\mathrm{R}$ version 3.3.1 (R Core Team 2016).

\section{Results}

A total of 518 lichen specimens were collected from 72 transects, which included 229 lichen species of 71 genera (Appendix 1). 95 species belonged to the foliose growth form, 87 species were crustose, 44 species fruticose and 3 species were leprose. With regard to the substrate preference, 157 species were corticolous, 55 saxicolous, 14 muscicolous and 3 terricolous species. Green algal photobionts were associated with 205 lichen species, while the remaining 24 lichen species were associated with cyanobacteria. A TukeyHSD test showed significant differences in lichen species richness between cultivated and other land-use types $(p<0.05)$ (Appendix 2a).

\section{Species richness between land-use types}

According to land-use types, 174 species were recorded from exploited forests with the highest number of foliose lichens (77 species), followed by 172 species on natural forests, dominated again by foliose lichens (70 species). Likewise, the highest number of corticolous species (151 species) was recorded from natural forests followed by exploited forests with 135 species.

\section{Species richness and canopy openness}

Total species richness showed a significant monotonic decline with canopy openness (Figure 2a). Such a monotonic decline of species richness was also found for specific growth forms, specific photobiont species richness and species richness of corticolous of specific substrate types (Figure 2, Appendix 3). As an exception, a significant monotonic increase was found for saxicolous species richness towards higher canopy openness (Figures 2e, Appendix 3). An optimum of total lichen richness was found at low canopy openness with 20.1 species predicted at $10 \%$ canopy openness, with a gradual decline towards higher canopy openness (Figure 2a). Similarly, species numbers of crustose and fruticose lichens showed a decline towards higher canopy openness, with a predicted species number of 6.4 and 5.2 species at $10 \%$ canopy openness respec- 

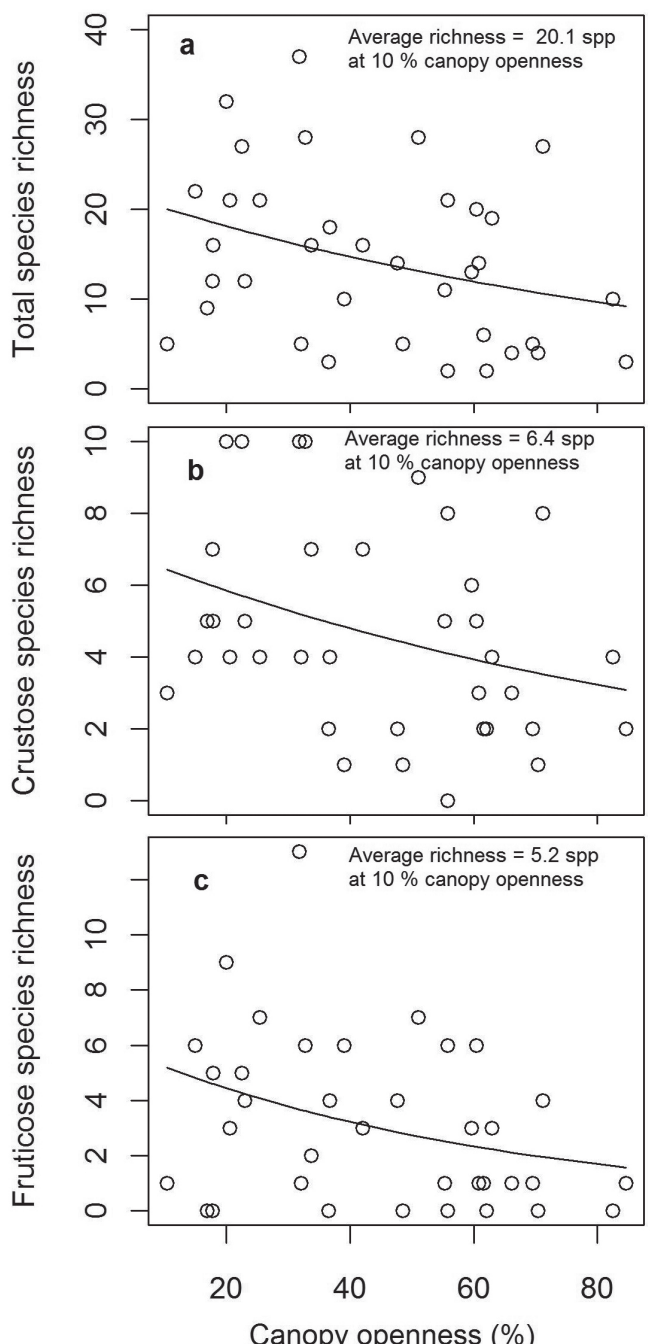

Figure 2 - Relationship between lichen species richness and canopy openness. a-g: a) total species richness; $b$ \& c) species richness of specific grwoth forms; $d \&$ e) species richness of specific substrate types and $f \ll g)$ specific photobiont species richness. The fitted regression lines represent Model 1 (Appendix 3).

tively (Figures 2b \& c). Regression analysis was not performed for the leprose growth form because only three species presented this feature. Regarding the four substrate categories, corticolous lichen richness also showed a gradual decline with increasing canopy openness, with an average of 19.8 species at $10 \%$ canopy openness (Figure 2d). In contrast, saxicolous lichen richness had a positive trend with increasing canopy openness with an average of 7.4 species at $85 \%$ canopy openness (Figure 2e). GLM was not performed for muscicolous and terricolous species as their number was too low (14 and 3 species respectively). With respect to photobiont type, both cyanolichens and green algal lichens exhibited a significant decrease with canopy openness, with an average of 2.9 species of cy-

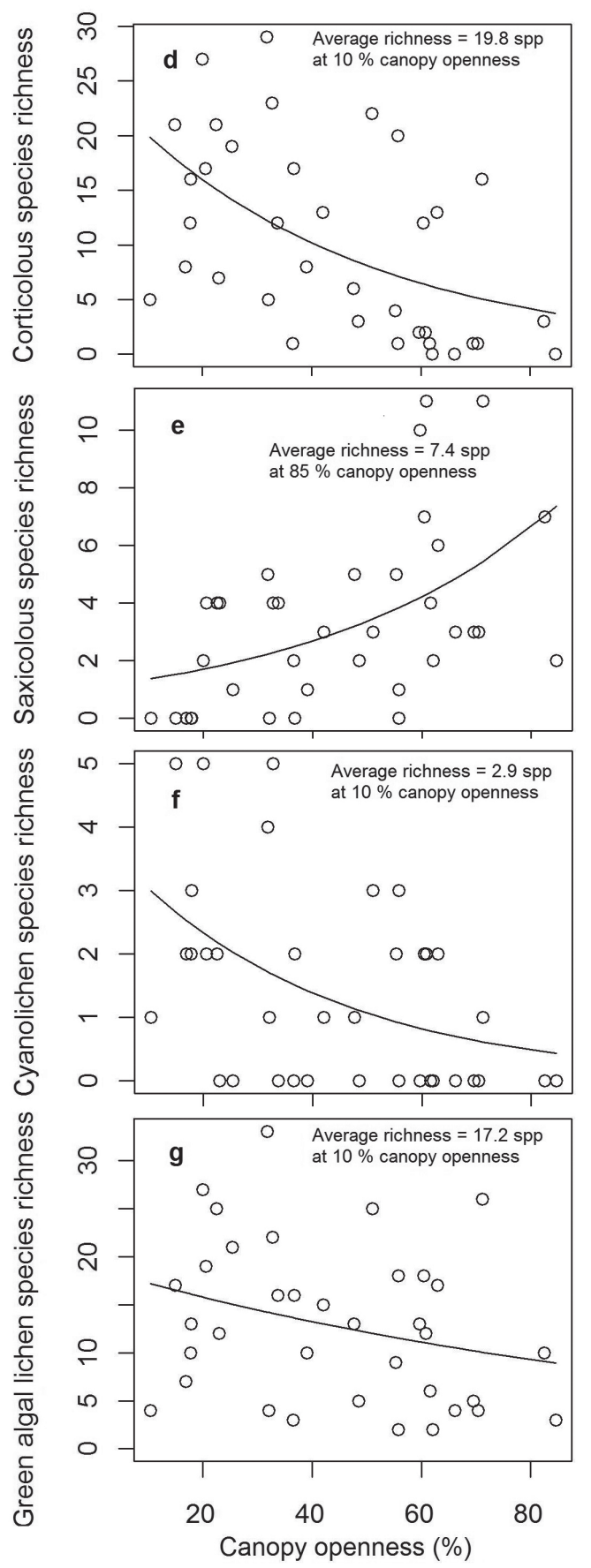

anolichens, 17.2 species of green algal lichens at $10 \%$ canopy openness (Figures $2 \mathrm{f} \& \mathrm{~g}$ ) respectively.

\section{Species richness along elevation}

There is a significant correlation of the total lichen species richness with the elevation and canopy openness $(p \leq 0.05)$. Total species richness of lichens and species richness of specific growth forms, specific substrate types and specific photobiont types, except species richness of leprose, muscicolous, terricolous lichens, showed a significant $(p \leq 0.05)$ monotonic increase with elevation (Figures 3a-g, Appendix 3). A total richness of 21.9 species was predicted at $3800 \mathrm{~m}$ with a predicted species richness of 6.3 crustose, 10.3 foliose, 5.2 fruticose, 16.5 corticolous and 2.4 cyanoli- 

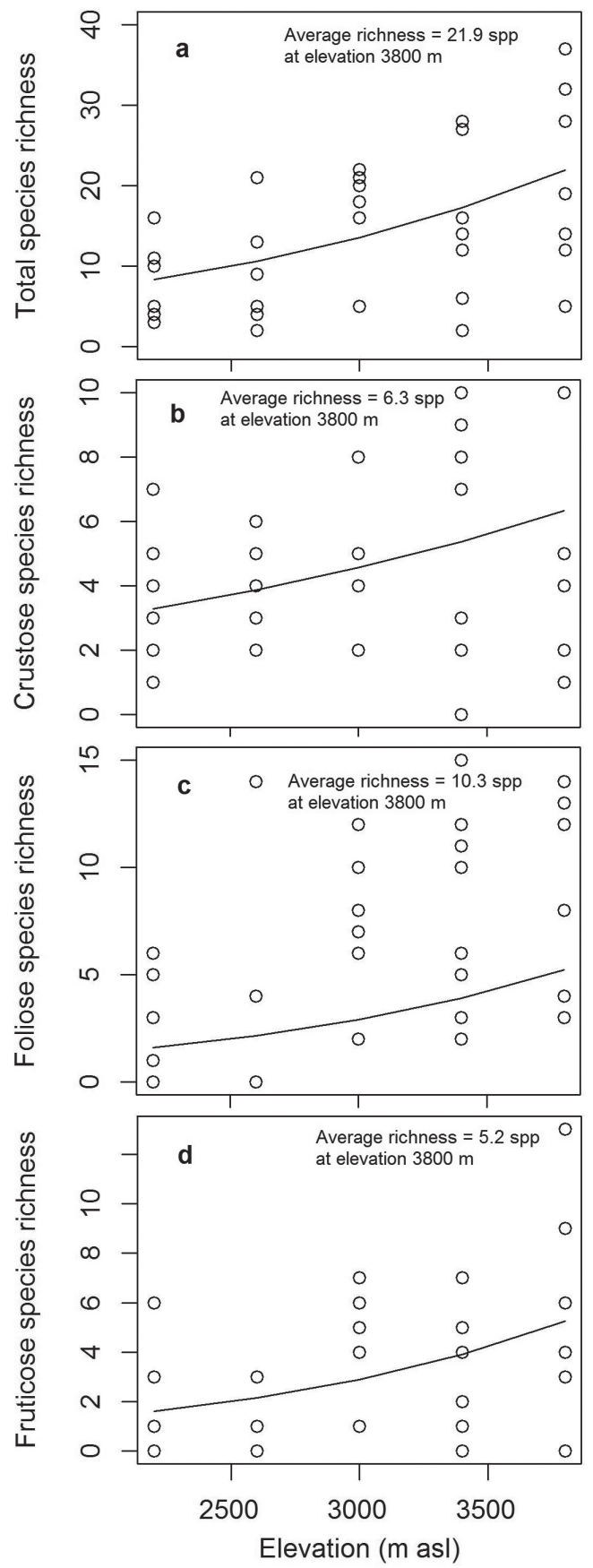

chens and 19.5 green algal lichen species at $3800 \mathrm{~m}$ (Figures $3 a-g$ ). The regression analysis results showing the best selected model for each response variable is shown in Appendix 3.

\section{Species composition}

The length of the first DCA axis was 8.01 SD units (Table 2) that indicated a high beta diversity with almost complete species turnover between transects. The first two DCA axes explained $12.3 \%$ of the total variance in the data matrix.

In CCA, the environmental variables elevation, canopy openness and land-use explained $21 \%$ of the total species variation variance (Table 3). CCA axis I was significantly correlated with elevation, while CCA
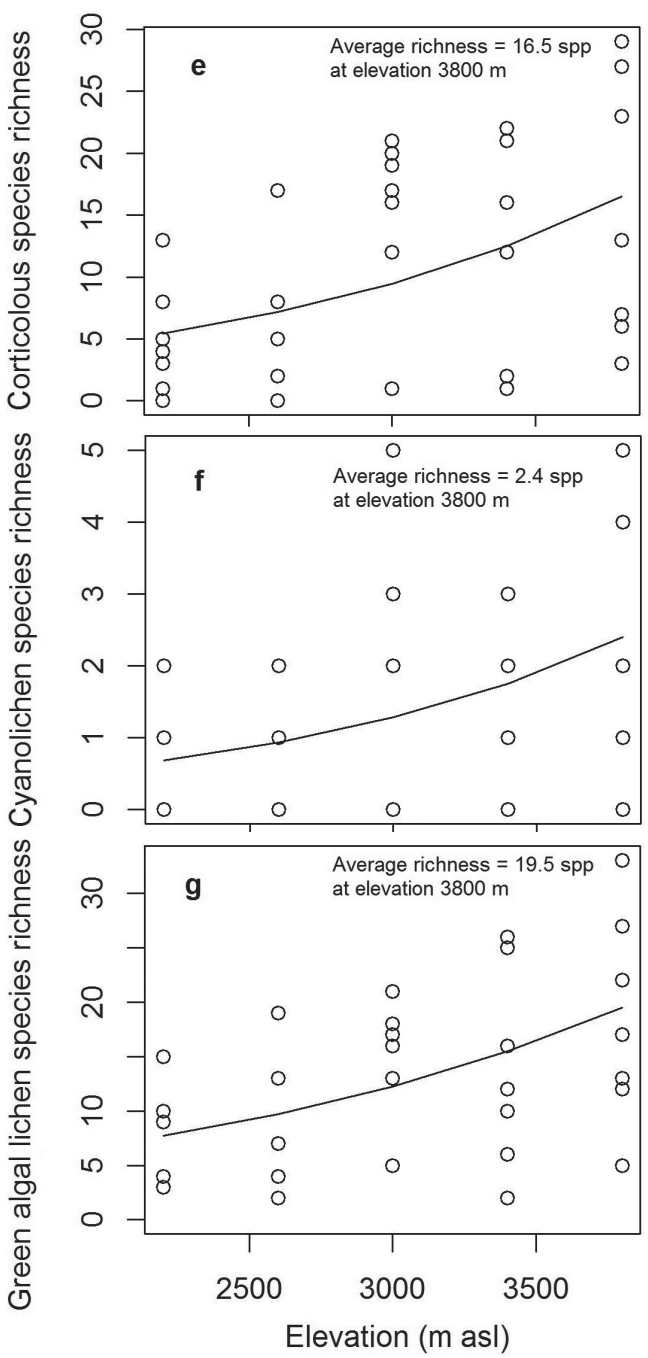

Figure 3 - Relationship between lichen species richness and elevation. a-g: a) total species richness; $b-d$ ) species richness of specific grwoth forms; e) species richness of specific substrate types and $\mathrm{do}$ g) specific photobiont species richness. The fitted regression lines represent Model 1 (Appendix 3).

axis II was highly correlated with canopy openness and land-use types (Figure 4, Appendix 2b). Along the CCA axis I, the highest abundance of Aspicilia contorta, Chaenotheca chrysocephala, Evernia mesomorpha, Leptogium burnetiae, Umbilicaria indica var. indica and Usnea longissima showed more preference towards high elevation, while species such as Cladonia scabriuscula, Heterodermia comosa, Lecanora cenisia showed high preference towards low elevation. Likewise, along the CCA axis II, species composition of Aspicilia caesiocinerea, Coccocarpia erythroxyli, Phaeophyscia ciliata, Umbilicaria badia, Xanthoria fallax showed higher abundance towards higher canopy openness, while species like Caloplaca farinosa, Hypogymnia vittata, Cladonia crispata var. cetrariiformis, Usnea bimalayana, Chaenotheca chryso- 
Table 1 - Environmental correlation coefficient matrix (Pearson correlation) among variables used during the study ( $p \leq 0.05)$. elv $=$ elevation, cano $=$ canopy openness, $s p n=$ total species number, $c r u=$ crustose species number, fol=foliose species number, $f r u=$ fruticose species number, lep $=$ leprose species number, cort $=$ corticolous species, musc $=$ muscicolous species, saxi $=$ saxicolous species, terr = terricolous species, blgrn = blue green algae and grnal= green algae

\begin{tabular}{|l|l|l|l|l|l|l|l|l|l|l|l|l|l|}
\cline { 2 - 14 } \multicolumn{1}{c|}{} & Elev & Canopy & Spn & Cru & Fol & Fru & Lep & Cort & Musc & Saxi & Terr & Blgrn & Grnal \\
\hline Elev & 0.00 & 1.00 & 0.06 & 0.85 & 0.06 & 0.47 & 1.00 & 0.26 & 0.65 & 1.00 & 1.00 & 0.81 & 0.07 \\
\hline Canopy & 0.29 & 0.00 & 1.00 & 1.00 & 1.00 & 1.00 & 1.00 & 0.06 & 1.00 & 0.09 & 1.00 & 0.28 & 1.00 \\
\hline Spn & 0.00 & 0.05 & 0.00 & 0.00 & 0.00 & 0.00 & 1.00 & 0.00 & 0.06 & 1.00 & 1.00 & 0.00 & 0.00 \\
\hline Cru & 0.02 & 0.05 & 0.00 & 0.00 & 0.00 & 0.00 & 1.00 & 0.00 & 0.78 & 1.00 & 1.00 & 0.00 & 0.00 \\
\hline Fol & 0.00 & 0.18 & 0.00 & 0.00 & 0.00 & 0.00 & 1.00 & 0.00 & 0.61 & 1.00 & 1.00 & 0.00 & 0.00 \\
\hline Fru & 0.01 & 0.05 & 0.00 & 0.00 & 0.00 & 0.00 & 1.00 & 0.00 & 0.00 & 1.00 & 1.00 & 0.00 & 0.00 \\
\hline Lep & 0.41 & 0.64 & 0.21 & 0.10 & 0.47 & 0.50 & 0.00 & 1.00 & 1.00 & 1.00 & 1.00 & 1.00 & 1.00 \\
\hline Cort & 0.01 & 0.00 & 0.00 & 0.00 & 0.00 & 0.00 & 0.33 & 0.00 & 0.61 & 1.00 & 1.00 & 0.00 & 0.00 \\
\hline Musc & 0.02 & 0.29 & 0.00 & 0.02 & 0.01 & 0.00 & 0.67 & 0.01 & 0.00 & 1.00 & 1.00 & 0.37 & 0.07 \\
\hline Saxi & 0.27 & 0.00 & 0.16 & 0.33 & 0.04 & 0.84 & 0.32 & 0.55 & 0.36 & 0.00 & 1.00 & 1.00 & 1.00 \\
\hline Terr & 0.68 & 0.09 & 0.58 & 0.31 & 0.97 & 0.38 & 0.60 & 0.44 & 0.83 & 0.34 & 0.00 & 1.00 & 1.00 \\
\hline Blgrn & 0.02 & 0.01 & 0.00 & 0.00 & 0.00 & 0.00 & 0.93 & 0.00 & 0.01 & 0.56 & 0.51 & 0.00 & 0.00 \\
\hline Grnal & 0.00 & 0.09 & 0.00 & 0.00 & 0.00 & 0.00 & 0.14 & 0.00 & 0.00 & 0.09 & 0.61 & 0.00 & 0.00 \\
\hline
\end{tabular}

Table 2 - DCA summary of the study site.

\begin{tabular}{|l|l|r|r|r|r|}
\hline DCA Axis & I & \multicolumn{1}{|l|}{ II } & \multicolumn{1}{|l|}{ III } & \multicolumn{1}{|l|}{ IV } & Total inertia \\
\hline Eigenvalues & 0.63 & 0.50 & 0.40 & 0.33 & 9.16 \\
\hline Axis lengths & 8.01 & 6.30 & 4.28 & 3.77 & \\
\hline $\begin{array}{l}\text { Cumulative \% vari- } \\
\text { ance of species data }\end{array}$ & 6.87 & 12.32 & 16.71 & 20.30 & \\
\hline
\end{tabular}

cephala showed a higher abundance towards low canopy openness (Figure 4).

Similarly, species like Phaeophyscia endococcina, Lecanora polytropa, Umbilicaria badia, Parmotrema subarnoldii showed high abundance towards open habitats and cultivated land, while species like Aspicilia cinerea, Hypotrachyna scytophylla, Parmelina quercina, Heterodermia obscurata, Stereocaulon paradoxum, Rhizoplaca chrysoleuca showed high abundance in meadows. Likewise, $H y$ potrachyna cirrhata, Hypotrachyna nepalensis, Cetrelia cetrarioides, Parmotrema pseudonilgherrense, Usnea compressula showed high abundance towards exploited forest and species like Lobaria retigera, Cladonia crispata var. cetrariiformis, Hypogymnia vittata, Caloplaca farinosa, Nephromopsis abtii showed high abundance towards natural forest landscapes (Figure 4).

\section{Discussion}

Lichen species richness and composition along gradients of land use, canopy openness and elevation

Our study indicated distinct effects of elevation, land use and canopy openness on lichen species richness and composition. We found a considerable variation in lichen species richness among the four selected land-use types, with decline of species richness from forest to cultivated land. These findings are in accordance with other studies like Stofer et al. (2006), who also observed decreasing lichen species richness from natural forest landscape to open agricultural landscape in a large-scale study covering several European biogeographic zones.
Table 3 - DCA analysis summary of the study site.

\begin{tabular}{|l|r|r|r|}
\cline { 2 - 4 } \multicolumn{1}{c|}{} & Inertia & Proportion & Rank \\
\hline Total & 9.15 & 1.00 & \\
\hline Constrained & 1.92 & 0.21 & 6 \\
\hline Unconstrained & 7.23 & 0.79 & 29 \\
\hline
\end{tabular}

Our study revealed a monotonic decrease in total lichen species richness with increasing canopy openness. In the present study, low canopy openness of about $10 \%$ still supported a high number of lichen species. In the steep Himalayan mixed forests, canopy openness of $10 \%$ and more is likely to provide sufficient light into the forest stand and, in general, light limitation does not seem to be a major limiting factor for lichen species richness in the mountain forests of KCA.

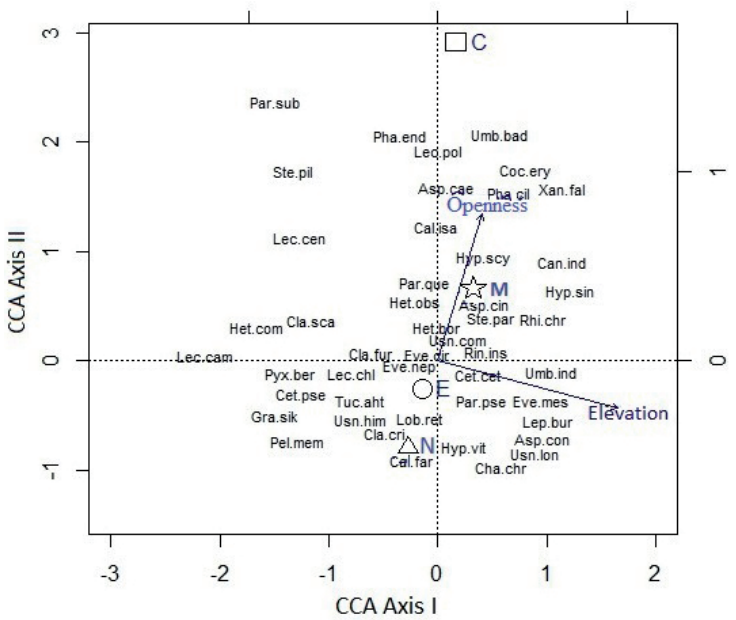

Figure 4 - Canonical Correspondence Analysis (CCA) of lichen composition constraint by elevation, canopy openness and land-use types; $C=$ Cultivated, $M=$ Meadow, $E=$ Exploited, and $N=$ Natural. Arrow indicates the direction of increasing values and their length is proportional to the correlation between the variable and the plot scores (not shown) on the two ordination axes. Land-use types are shown as centroids. For full names of species see Appendix 1. 
As trees are an important factor explaining lichen species composition and richness (Mežaka et al. 2008; Odor et al. 2013), meadows and natural forests seemed to provide lichen-rich habitats because of a high diversity and abundance of trees. The exploited forest type with varying disturbance intensity still maintained a reasonable diversity of microhabitats for epiphytic lichens, but some species that depend on semi-shaded habitats and high moisture in natural forests, such as corticolous lichens, are declining in exploited forests. Pinokiyo et al. (2008) also found the maximum number of corticolous lichens in dense forest. In the present study, we found high saxicolous lichen richness in meadows, because a high abundance of rocks and boulders are exposed on meadows, where litter does not continuously cover their surface. Exposed rock surfaces can support more saxicolous lichens than in closed forests, where slightly inclined rock surfaces are often covered with litter. On cultivated lands, slightly inclined rock surfaces are often disturbed by human influence to remove them or to use them for various activities related to farming. Frequent and intense disturbance of rock surfaces in agricultural land is a significant difference to European land-use gradients, where Wolseley et al. (2006) recorded high saxicolous richness in farmland including cultivated land.

The saxicolous species richness revealed a gradual increase of species richness with increasing canopy openness and reached an average of 7.4 species per transect at $85 \%$ openness, which corresponds to meadows and open cultivated land. Rocks and boulders inside forest landscapes are primarily covered by litter or mosses and also have a low exposition to solar radiation. However, corticolous species richness showed a decline with increasing openness and reached an average of 19.8 species at $10 \%$ openness. Because corticolous lichens in the studied land-use gradients form a more species-rich species pool than saxicolous species, the observed decline of saxicolous species richness is overcompensated by a stronger increase of epiphytic lichens. As the lichen diversity is related to tree diversity, density (Baniya et al. 1999; Li et al. 2011; Li et al. 2013b, 2013a) and humidity (Pinokiyo et al. 2008), cultivated landscapes bear a limited number of trees, shrubs and fewer rocks and boulders as well as less humidity. The resulting lower epiphytic lichen species richness cannot be compensated by an increased density of boulders and bare rocks, which are generally covered with lichen vegetation under an open sky receiving direct solar radiation.

The lichen richness pattern is also closely related to the management practices of the particular landscape, e. g. the protected area. The traditional shifting cultivation practice common to this area (Aryal et al. 2010) is significantly explained after finding of declining lichen richness pattern with open canopy. The shifting cultivation practice opens up a landscape which seems not to support lichen richness and its diversity pattern. Further, the shifting cultivation practice is also common to Makalu-Barun areas of East Nepal. Thus, future diversity of lichen seems in a difficult situation. Conservation of lichen will automatically conserve the landscape.

In addition to the differences between land-use types, our study clearly indicated a distinct variation in species richness along the elevational gradient studied. We found a linear relationship with increasing elevation. Cobanoglu and Sevgi (2009) reported a similar pattern for epiphytic lichens with elevations from $1300 \mathrm{~m}$ to $1900 \mathrm{~m}$ in Turkey. However, a majority of former studies reported an unimodal relationship (Bruun et al. 2006; Grytnes et al. 2006; Baniya et al. 2010, 2012). Unlike these studies, which generally covered long elevational gradients, our study was more closely confined to a local scale, with an elevational gradient covering temperate to subalpine forests, but not reaching areas above the timberline. Therefore our linear relationship can be interpreted as part of an unimodal relationship on larger scales.

Lichen species composition showed a strong species turnover along CCA axis I (elevation) and CCA axis II (land use-types). Natural and exploited forests supported diverse lichen vegetation which decreased towards meadows and cultivated land. These results confirm findings from European land-use gradients from forest to agricultural land-use types (Stofer et al. 2006).

\section{Conclusion}

We conclude that besides elevation as a general climate proxy, differences in land use, which directly affect canopy openness, are the two main general factors of both lichen species richness and composition in this area of the Himalayas in Nepal. Forests with diverse habitats and relatively low canopy openness harbour more lichen species than meadows and cultivated land. However, elevation and canopy openness are not direct drivers. Canopy openness influences light intensity and relative moisture on the forest floor and tree trunks, which directly affect lichen diversity. In addition, elevation serves as a general climate proxy for temperature or precipitation, which more directly influences both species richness and composition of lichen communities. Highest species richness of lichens was reached at the highest altitudinal level of our survey, indicating that the maximum total species richness of lichens as well as the richness of most of the studied species groups is at or above $3800 \mathrm{~m}$ in this part of the Himalayas.

\section{Acknowledgement}

We thank the Swiss National Science Foundation (JRP IZ70Z0_131338 to CS, MN and K. K. Shrestha) for financial support. We are also grateful to all members of the CDB-WSL Project, Prof. Dr. Krishna Kumar Shrestha, Prof. Dr. Khadga Basnet, Dr. Jyoti Pd. Gajurel, Mr. Shiva Devkota, Mr. Sanjeev Kumar 
Rai, Mr. Hem Bdr. Katuwal, Mr. Yam Aryal and Mr. Rajesh Tamang for their kind support. We thank all local people of Ghunsa, KCA, and Utra Kumar Rai for his help with collecting lichens in the field.

\section{References}

Anonymous 2009. Kanchenjunga conservation area. Kanchenjunga conservation area management council.

Anonymous 2011. Kanchenjunga conservation area. Kanchenjunga conservation area management council.

Aryal, K.P., E.E. Kerkhoffn, N. Maskey \& R. Sherchan 2010. Shifting Cultivation in the Sacred Himalayan Landscape: A case study in the Kanchenjunga Conservation Area. WWF Nepal.

Awasthi, D.D. 1991. A key to the microlichens of India, Nepal and Sri-Lanka. Bibliotheca Lichenologica 40: 1-137.

Awasthi, D.D. 2007. A compendium of the macrolichens from India, Nepal and Sri-Lanka. India.

Baniya, C.B., G.P.S. Ghimire \& B. Kattel 1999. Diversity of lichens in Nepal. Banko Jankari 9: 26-28.

Baniya, C.B., T. Solhøy, Y. Gauslaa \& M.W. Palmer 2010. The elevation gradient of lichen species richness in Nepal. The Lichenologist 42: 83-96.

Baniya, C.B., T. Solhøy, Y. Gauslaa \& M.W. Palmer 2012. Richness and composition of vascular plants and cryptogams along a high elevational gradient on Buddha Mountain, Central Tibet. Folia Geobotanica 47: 135-151.

Bergamini, A., C. Scheidegger, S. Stofer, P. Carvalho, S. Davey, M. Dietrich, F. Dubs, E. Farkas, U. Groner, \& K. Kaerkkaeinen 2005. Performance of macrolichens and lichen genera as indicators of lichen species richness and composition. Conservation Biology 19: 1051-1062.

Bruun, H.H., J. Moen, R. Virtanen, J.A. Grytnes, L. Oksanen \& A. Angerbjörn 2006. Effects of altitude and topography on species richness of vascular plants, bryophytes and lichens in alpine communities. Journal of Vegetation Science 17: 37-46.

Chaudhary, R.P. 1998. Biodiversity in Nepal: Status and conservation: Bangkok, Thailand.

Cobanoglu, G. \& O. Sevgi 2009. Analysis of the distribution of epiphytic lichens on Cedrus libani in Elmali Research Forest (Antalya, Turkey). Journal of Environmental Biology 30: 205-212.

Frazer, G.W., C.D. Canham \& K.P. Lertzman 1999. Gap Light Analyzer (GLA), Version 2.0: Imaging software to extract canopy structure and gap light transmission indices from true-colour fisheye photographs, user's manual and program documentation. Simon Fraser University, Burnaby, British Columbia, and the Institute of Ecosystem Studies, Millbrook, New York. (http://www.ecostudies.org)

Gautam, C.M. \& T. Watanabe 2004. Reliability of Land Use/Land Cover Assessment in Montane Nepal: A Case Study in the Kangchenjunga Conservation Area (KCA). Mountain Research and Development 24: 35-43.
Giordani, P., G. Incerti, G. Rizzi, F. Ginaldi, S. Viglione, I. Rellini, G. Brunialti, P. Malaspina \& P. Modenesi 2010. Land use intensity drive the local variation of lichen diversity in Mediterranean ecosystems sensitive to desertification. Bibliotheca Lichenologica 105: 139-148.

Grytnes, J.A., E. Heegaard \& P.G. Ihlen 2006. Species richness of vascular plants, bryophytes, and lichens along an altitudinal gradient in western Norway. Acta oecologica 29: 241-246.

Hale, M.E. 1983. The biology of lichens. London.

Hill, M.O. \& H.G. Gauch 1980. Detrended Corrrespondence Analysis: An Improved Ordination Technique. Vegatatio 42: 47-58.

Li, S., W.Y. Liu \& D.W. Li 2013a. Bole epiphytic lichens as potential indicators of environmental change in subtropical forest ecosystems in southwest China. Ecological Indicators 29: 93-104.

Li, S., W.Y. Liu \& D.W. Li 2013b. Epiphytic lichens in subtropical forest ecosystems in southwest China: Species diversity and implications for conservation. Biological Conservation 159: 88-95.

Li, S., W. Liu, L. Wang, W. Ma \& L. Song 2011. Biomass, diversity and composition of epiphytic macrolichens in primary and secondary forests in the subtropical Ailao Mountains, SW China. Forest Ecology and Management 261: 1760-1770.

Löbel, S., T. Snäll \& H. Rydin 2006. Species richness patterns and metapopulation processes-evidence from epiphyte communities in boreo nemoral forests. Ecography 29: 169-182.

Lücking, R., B.P. Hodkinson \& S.D. Leavitt 2016. The 2016 classification of lichenized fungi in the Ascomycota and Basidiomycota-Approaching one thousand genera. The Bryologist 119: 361-416.

Marmor, L., T. Tõrra, L. Saag \& T. Randlane 2012. Species richness of epiphytic lichens in coniferous forests: the effect of canopy openness. Annales Botanici Fennici 49: 352-358.

McCullagh, P. \& J.A. Nelder 1989. Generalized Linear Models ( $2^{\text {nd }}$ ed.). London.

Mežaka, A., G. Brūmelis \& A. Piterāns 2008. The distribution of epiphytic bryophyte and lichen species in relation to phorophyte characters in Latvian natural old-growth broad leaved forests. Folia Cryptogamica Estonica 44: 89-99.

Mežaka, A., G. Brūmelis \& A. Piterāns 2012. Tree and stand-scale factors affecting richness and composition of epiphytic bryophytes and lichens in deciduous woodland key habitats. Biodiversity and Conservation 21: 3221-3241.

MFSC 2009. Nepal Fourth National Report to the Convention of Biological Diversity. Singha Durbar, Kathmandu, Nepal: Ministry of Forests and Soil Conservation, Government of Nepal.

Motiejûnaitë, J. \& W. Faùtynowicz 2005. Effect of land-use on lichen diversity in the transboundary region of Lithuania and northeastern Poland. Ekologija 3: 34-43. 
Odor, P., L. Kiraly, F. Tinya, F. Bortignon \& J. Nascimbene 2013. Patterns and drivers of species composition of epiphytic bryophytes and lichens in managed temperate forests. Forest Ecology and Management 306: 256-265.

Oksanen, J., F.G. Blanchet, M. Friendly, R. Kindt, P. Legendre, D. McGlinn, P.R. Minchin, R.B. O’Hara, G.L. Simpson, P. Solymos, M. H.H. Stevens, E. Szoecs \& H. Wagner. 2016. vegan: Community Ecology Package. R package version 2.4-0. http:/ /CRAN.R-project. org $/$ package $=$ vegan

Pinokiyo, A., K.P. Singh \& J.S. Singh 2008. Diversity and distribution of lichens in relation to altitude within a protected biodiversity hot spot, north-east India. The Lichenologist 40: 47-62.

R Core Team 2016. R: A language and environment for statistical computing. R Foundation for Statistical Computing, Vienna, Austria. URL http://www.Rproject.org/.

Rai, H., R. Khare, R.K. Gupta, \& D.K. Upreti 2011. Terricolous lichens as indicator of anthropogenic disturbances in a high altitude grassland in Garhwal (Western Himalaya), India. Botanica Orientalis: Journal of Plant Science 8: 16-23.

Scheidegger, C., M.P. Nobis \& K.K. Shrestha 2010. Biodiversity and livelihood in land-use gradients in an era of climate change-outline of a Nepal-Swiss research project. Botanica Orientalis: Journal of Plant Science 7: 7-17.

Scheidegger, C. \& S. Werth 2009. Conservation strategies for lichens: insights from population biology. Fungal Biology Reviews 23: 55-66.

Sharma, L.R. 1995. Enumerations of the Lichens of Nepal. Biodiversiy Profile Project. Tec. Pub. No.3, DNPWC, Kathmandu, Nepal.

Shrestha, K.K., \& S.K. Ghimire 1996. Plant diversity inventory of poposed Kanchenjunga Conservation Area (Ghunsa and Simbua Valleys). Kathmandu, Nepal: WWF Nepal Progaram Report series 22.

Singh, K.P. \& G.P. Sinha 2010. Indian lichens: an annotated checklist. Botanical Survey of India, Ministry of Environment and forests.

Stofer, S., A. Bergamini, G. Aragon, P. Carvalho, B.J. Coppins, S. Davey, M. Dietrich, E. Farkas, K. Karkkainen, C. Keller, L. Lokos, S. Lommi, C. Maguas, R. Mitchell, P. Pinho, V.J. Rico, A.M. Truscott, P.A. Wolseley, A. Watt \& C. Scheidegger 2006. Species richness of lichen functional groups in relation to land use intensity. The Lichenologist 38: 331-353.

Tasser, E. \& U. Tappeiner 2002. Impact of land use changes on mountain vegetation. Applied vegetation science 5: 173-184.
Wolseley, P.A., S. Stofer, R. Mitchell, A.M. Truscott, A. Vanbergen, J. Chimonides \& C. Scheidegger 2006. Variation of lichen communities with landuse in Aberdeenshire, UK. Lichenologist 38: 307-322.

\section{Authors}

Til Bikram Chongbang - corresponding author holds an M.Sc. in Botany from Tribhuvan University, Kathmandu, Nepal. Now a member of the biology teaching staff at the National School of Sciences, Lainchour, Kathmandu, he is particularly interested in lichens and ethnobotany. E-mail: tbchongbang@ yahoo.com

\section{Christine Keller}

is an expert in lichen taxonomy and ecology. She is a member of the scientific staff at the Swiss Federal Institute for Forest, Snow and Landscape Research WSL, Birmensdorf. E-mail: christine.keller@wsl.ch

\section{Michael Nobis'}

is a botanist and macroecologist with a research focus on trait-environment relationships, species distribution modelling, species migration and biological invasions. He is a member of the scientific staff at the Swiss Federal Institute for Forest, Snow and Landscape Research WSL. E-mail: michael.nobis@wsl.ch

\section{Christoph Scheidegger ${ }^{1}$}

focuses in his research on the conservation biology of lichens and plants, population genetics and landscape ecology, and biodiversity assessment and evaluation at the landscape level. He recently coordinated a research project in Nepal. He is a senior scientist and group leader at the Swiss Federal Institute for Forest, Snow and Landscape Research WSL. E-mail: christoph.scheidegger@wsl.ch

\section{Chitra Bahadur Baniya}

is Associate Professor of Ecology and Resource Management at the Central Department of Botany, Tribhuvan University, Kathmandu, Nepal. His major field of interest is quantitative ecology of plants and lichens. His present teaching and research mainly focus on open-source programs, such as $R$ statistical packages and science in philosophy. E-mail: cbbaniya@ gmail.com

1 Swiss Federal Institute for Forest, Snow and Landscape Research WSL, Zürcherstrasse 111, CH8903 Birmensdorf. 


\section{Appendices}

Appendix 1 - List of lichens, their family, growth forms, substrate groups, photobiont partner and frequency of occurrence along land use types in the study area. Cru - crustose, Fol-foliose, Fru - fruticose, Lep-leprose, Cort-corticolous, Musc-muscicolous, Saxi-saxicolous, Terr - terricolous, BGA - blue green alga, $G A$ - green alga, $C$ - cultivated land, $M$ - meadow, E-exploited forest, $F$ - natural forest.

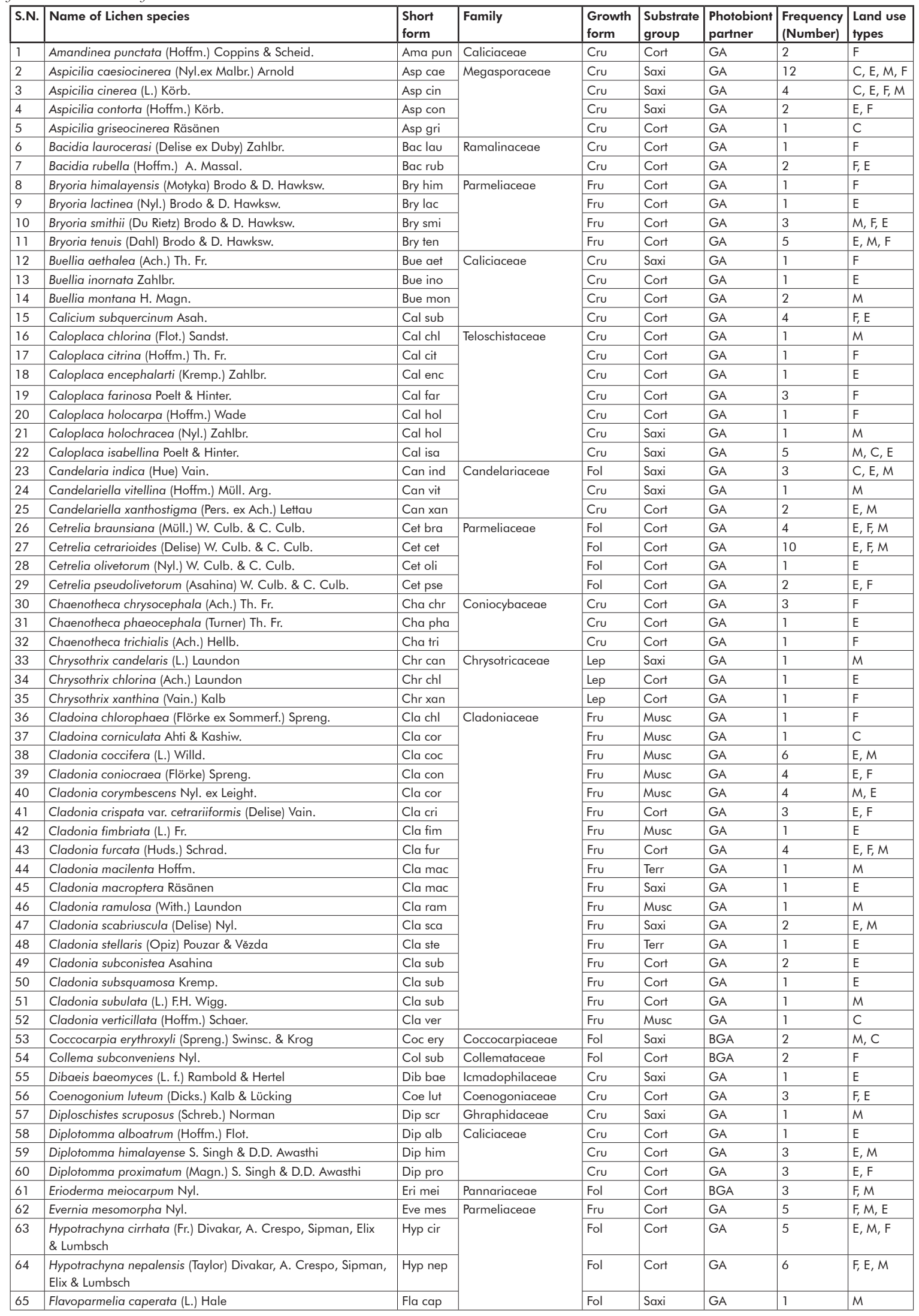




\begin{tabular}{|c|c|c|c|c|c|c|c|c|}
\hline S.N. & Name of Lichen species & \begin{tabular}{|l|}
$\begin{array}{l}\text { Short } \\
\text { form }\end{array}$ \\
\end{tabular} & Family & \begin{tabular}{|l|}
$\begin{array}{l}\text { Growth } \\
\text { form }\end{array}$ \\
\end{tabular} & \begin{tabular}{|l|}
$\begin{array}{l}\text { Substrate } \\
\text { group }\end{array}$ \\
\end{tabular} & \begin{tabular}{|l|}
$\begin{array}{l}\text { Photobiont } \\
\text { partner }\end{array}$ \\
\end{tabular} & \begin{tabular}{|l|} 
Frequency \\
(Number)
\end{tabular} & \begin{tabular}{|l}
$\begin{array}{l}\text { Land use } \\
\text { types }\end{array}$ \\
\end{tabular} \\
\hline 66 & Glyphis cicatricosa Ach. & Gly cic & \multirow[t]{7}{*}{ Graphidaceae } & Cru & Cort & GA & 1 & $\mathrm{~F}$ \\
\hline 67 & Graphis nigroglauca Leight. & Gra nig & & Cru & Cort & GA & 1 & $\mathrm{~F}$ \\
\hline 68 & Graphis pyrrhocheiloides Zahlbr. & Gra pyr & & Cru & Cort & GA & 3 & $E, F$ \\
\hline 69 & Graphis rimulosa (Mont.) Trevis. & Gra rim & & Cru & Cort & GA & 1 & $\mathrm{~F}$ \\
\hline 70 & Graphis scripta (L.) Ach. & Gra scr & & Cru & Cort & GA & 4 & $E, F$ \\
\hline 71 & Graphis sikkimensis Nagarkar \& Patw. & Gra sik & & Cru & Cort & GA & 5 & F, E \\
\hline 72 & Graphis sorediosa Nagarkar \& Patw. & Gra sor & & Cru & Cort & GA & 1 & $\mathrm{~F}$ \\
\hline 73 & Haematomma puniceum (Sm. ex Ach.) Massal. & Hae pun & Haematommataceae & Cru & Cort & GA & 6 & $F, M, E$ \\
\hline 74 & Heterodermia angustiloba (Müll. Arg.) D.D. Awasthi & Het ang & \multirow[t]{14}{*}{ Physciaceae } & Fol & Cort & GA & 3 & $E, F$ \\
\hline 75 & Heterodermia boryi (Fée) Kr.P. Singh \& S.R. Singh & Het bor & & Fol & Cort & GA & 6 & $E, M, C, F$ \\
\hline 76 & Heterodermia comosa (Eschw.) Follman \& Redon & Het com & & Fol & Cort & GA & 2 & $M, E$ \\
\hline 77 & Heterodermia diademata (Taylor) D.D. Awasthi & Het dia & & Fol & Cort & GA & 1 & $\mathrm{~F}$ \\
\hline 78 & Heterodermia firmula (Nyl.) Trevis. & Het fir & & Fol & Cort & GA & 1 & E \\
\hline 79 & Heterodermia incana (Stirt.) D.D. Awasthi & Het inc & & Fol & Cort & GA & 1 & E \\
\hline 80 & Heterodermia obscurata (Nyl.) Trevis. & Het obs & & Fol & Saxi & GA & 3 & $M, E$ \\
\hline 81 & Heterodermia pellucida (D.D. Awasthi) D.D. Awasthi & Het pel & & Fol & Cort & GA & 1 & E \\
\hline 82 & Heterodermia pseudospeciosa (Kurok.) W. Culb. & Het pse & & Fol & Cort & GA & 1 & E \\
\hline 83 & Heterodermia rubescens (Räsänen) D.D. Awasthi & Het rub & & Fol & Cort & GA & 2 & $E, F$ \\
\hline 84 & Heterodermia speciosa (Wulf.) Trevis. & Het spe & & Fol & Cort & GA & 3 & E \\
\hline 85 & Heterodermia togashii (Kurok.) D.D. Awasthi & Het tog & & Fol & Cort & GA & 6 & $E, M, F$ \\
\hline 86 & Heterodermia tremulans (Müll. Arg.) W. Culb. & Het tre & & Fol & Cort & GA & 1 & M \\
\hline 87 & Heterodermia verrucifera (Kurok.) W.A. Weber & Het ver & & Fol & Cort & GA & 1 & $\mathrm{~F}$ \\
\hline 88 & Hypogymnia hypotrypa (Nyl.) Rass. & Hyp hyp & \multirow[t]{10}{*}{ Parmeliaceae } & Fol & Cort & GA & 4 & F, E \\
\hline 89 & Hypogymnia vittata (Ach.) Gasil. & Hyp vit & & Fol & Cort & GA & 2 & F, E \\
\hline 90 & Hypotrachyna crenata (Kurok.) Hale & Hyp cre & & Fol & Saxi & GA & 1 & E \\
\hline 91 & Hypotrachyna exsecta (Taylor) Hale & Hyp exs & & Fol & Cort & GA & 1 & E \\
\hline 92 & Hypotrachyna infirma (kurok.) Hale & Hyp inf & & Fol & Cort & GA & 1 & $\mathrm{~F}$ \\
\hline 93 & Hypotrachyna majoris (Vain.) Hale & Hyp maj & & Fol & Cort & GA & 1 & $M$ \\
\hline 94 & Hypotrachyna revoluta (Flörke) Hale & Hyp rev & & Fol & Cort & GA & 1 & M \\
\hline 95 & Hypotrachyna scytophylla (Kurok.) Hale & Hyp scy & & Fol & Saxi & GA & 4 & $M, C, E$ \\
\hline 96 & Hypotrachyna sinuosa (Sm.) Hale & Hyp $\sin$ & & Fol & Saxi & GA & 4 & $C, M, E$ \\
\hline 97 & Hypotrachyna sublaevigata (Nyl.) Hale & Hyp sub & & Fol & Cort & GA & 1 & C \\
\hline 98 & Lasallia freyana D.D. Awasthi & Las fre & Umbilicariaceae & Fol & Saxi & GA & 1 & M \\
\hline 99 & Lecanora frustulosa (Dicks.) Ach. & Lec fru & \multirow[t]{12}{*}{ Lecanoraceae } & Cru & Saxi & GA & 1 & C \\
\hline 100 & Lecanora albella (Pers.) Ach. & Lec alb & & Cru & Cort & GA & 3 & $M, E$ \\
\hline 101 & Lecanora allophana (Ach.) Nyl. & Lec all & & Cru & Cort & GA & 1 & $\mathrm{E}$ \\
\hline 102 & Lecanora campestris (Schaer.) Hue & Lec cam & & Cru & Saxi & GA & 2 & $E, F$ \\
\hline 103 & Lecanora cenisia Ach. & Lec cen & & Cru & Saxi & GA & 4 & $M, F, C$ \\
\hline 104 & Lecanora chlarotera Nyl. & Lec chl & & Cru & Cort & GA & 8 & $F, E, M$ \\
\hline 105 & Lecanora intricata (Ach.) Ach. & Lec int & & Cru & Saxi & GA & 1 & M \\
\hline 106 & Lecanora polytropa (Ehrh.) Rabenh. & Lec pol & & Cru & Saxi & GA & 2 & $C, M$ \\
\hline 107 & Lecanora rugosella Zahlbr. & Lec rug & & Cru & Cort & GA & 4 & $\mathrm{~F}, \mathrm{E}$ \\
\hline 108 & Lecanora saligna (Schrad.) Zahlbr. & Lec sal & & Cru & Cort & GA & 1 & $\mathrm{~F}$ \\
\hline 109 & Lecanora strobilina Ach. & Lec str & & Cru & Cort & GA & 1 & M \\
\hline 110 & Lecanora varia (Hoffm.) Ach. & Lec var & & Cru & Cort & GA & 1 & M \\
\hline 111 & Lecidea betulicola (Kullh.) H. Magn. & Lec bet & \multirow[t]{4}{*}{ Lecideaceae } & Cru & Cort & GA & 1 & $\mathrm{~F}$ \\
\hline 112 & Lecidea erythrophaea Flörke ex Sommerf & Lec ery & & Cru & Cort & GA & 1 & $\mathrm{~F}$ \\
\hline 113 & Lecidea fuscoatra (L.) Ach. & Lec fus & & Cru & Saxi & GA & 1 & M \\
\hline 114 & Lecidea vorticosa (Flörke) Körb. & Lec vor & & Cru & Saxi & GA & 1 & M \\
\hline 115 & Lecidella elaeochroma (Ach.) M. Choisy & Lec ela & Lecanoraceae & Cru & Cort & GA & 1 & M \\
\hline 116 & Lepraria crassissima (Hue) Lettau & Lep cra & \multirow[t]{3}{*}{ Stereocaulaceae } & Cru & Saxi & GA & 1 & $M$ \\
\hline 117 & Lepraria ecorticata (J.R. Laundon) Kukwa & Lep eco & & Cru & Saxi & GA & 1 & M \\
\hline 118 & Lepraria membranacea (Dicks.) Vain. & Lep mem & & Cru & Cort & GA & 2 & $M, E$ \\
\hline 119 & Leptogium askotense D.D. Awasthi & Lep ask & \multirow[t]{6}{*}{ Collemataceae } & Fol & Cort & BGA & 1 & E \\
\hline 120 & Leptogium burnetiae Dodge & Lep bur & & Fol & Cort & BGA & 3 & $F, E, M$ \\
\hline 121 & Leptogium chloromelum (Sw.) Nyl. & Lep chl & & Fol & Cort & BGA & 1 & $\mathrm{~F}$ \\
\hline 122 & Leptogium cyanescens (Rabenh.) Körb. & Lep cya & & Fol & Cort & BGA & 1 & $\mathrm{~F}$ \\
\hline 123 & Leptogium pedicellatum P.M. Jørg. & Lep ped & & Fol & Cort & BGA & 7 & $E, F, M$ \\
\hline 124 & Leptogium saturninum (Dicks.) Nyl. & Lep sat & & Fol & Cort & BGA & 1 & M \\
\hline 125 & Lethariella cladonioides (Nyl.) krog & Let cla & Parmeliaceae & Fru & Cort & GA & 1 & M \\
\hline 126 & Lobaria isidiosa (Müll. Arg.) Vain. & Lob isi & Lobariaceae & Fol & Cort & BGA & 1 & $\mathrm{~F}$ \\
\hline 127 & Lobaria pindarensis Räsänen & Lob pin & & Fol & Cort & BGA & 3 & $\mathrm{~F}$ \\
\hline 128 & Lobaria retigera (Bory) Trev. & Lob ret & & Fol & Cort & BGA & 5 & $E, F$ \\
\hline 129 & Melanelia panniformis (Nyl.) Essl. & Mel pan & Parmeliaceae & Fol & Cort & GA & 1 & $M$ \\
\hline 130 & Melanelia tominii (Oxner) Essl. & Mel tom & & Fol & Saxi & GA & 2 & $M$ \\
\hline 131 & Menegazzia terebrata (Hoffm.) A. Massal. & Men ter & & Fol & Cort & GA & 6 & $E, F$ \\
\hline 132 & Mycobilimbia hunana (Zahlbr.) D.D. Awasthi & Myc hum & Lecideaceae & Cru & Terr & GA & 1 & C \\
\hline 133 & Mycoblastus affinis (Schaer.) T. Schaver & Myc aff & Tephromelatacae & Cru & Cort & GA & 2 & $\mathrm{~F}$ \\
\hline 134 & Myelochroa subaurulenta (Nyl.) Elix \& Hale & Mye sub & Parmeliaceae & Fol & Cort & GA & 1 & $\mathrm{~F}$ \\
\hline 135 & Nephroma isidiosum (Nyl.) Gyeln. & Nep isi & Nephromataceae & Fol & Musc & BGA & 1 & M \\
\hline 136 & Nephroma nakaoi Asahina & Nep nak & & Fol & Cort & BGA & 4 & $F, E, M$ \\
\hline 137 & Nephromopsis nephromoides (Nyl.) Ahti \& Randl. & Nep nep & Parmeliaceae & Fol & Cort & GA & 1 & E \\
\hline 138 & Ochrolechia androgyna (Hoffm.) Arnold & Och and & Ochrolechiaceae & Cru & Saxi & GA & 1 & $\mathrm{~F}$ \\
\hline 139 & Ochrolechia parellula (Müll. Arg.) Zahlbr. & Och par & & Cru & Saxi & GA & 1 & $\mathrm{~F}$ \\
\hline 140 & Ochrolechia rosella (Müll. Arg.) Vers. & Och ros & & Cru & Cort & GA & 8 & $E, F, M$ \\
\hline
\end{tabular}




\begin{tabular}{|c|c|c|c|c|c|c|c|c|}
\hline S.N. & Name of Lichen species & $\begin{array}{l}\text { Short } \\
\text { form }\end{array}$ & Family & $\begin{array}{l}\text { Growth } \\
\text { form }\end{array}$ & \begin{tabular}{|l|}
$\begin{array}{l}\text { Substrate } \\
\text { group }\end{array}$ \\
\end{tabular} & \begin{tabular}{|l|}
$\begin{array}{l}\text { Photobiont } \\
\text { partner }\end{array}$ \\
\end{tabular} & \begin{tabular}{|l|} 
Frequency \\
(Number)
\end{tabular} & $\begin{array}{l}\text { Land use } \\
\text { types }\end{array}$ \\
\hline 141 & Parmotrema thomsonii (Stirt.) A. Crespo, Divakar \& Elix & Par tho & \multirow[t]{16}{*}{ Parmeliaceae } & Fol & Cort & GA & 1 & E \\
\hline 142 & Parmelia squarrosa Hale & Par squ & & Fol & Cort & GA & 2 & M \\
\hline 143 & Parmeliella cinerata Zahlbr.) P.M. Jørg. & Par cin & & Fol & Cort & BGA & 1 & E \\
\hline 144 & Parmelina quercina (Willd.) Hale & Par que & & Fol & Cort & GA & 4 & $F, C, E, M$ \\
\hline 145 & Parmotrema cetratum (Ach.) Hale & Par cet & & Fol & Cort & GA & 2 & $E, F$ \\
\hline 146 & Parmotrema latissimum (Fée) Hale & Par lat & & Fol & Cort & GA & 1 & $\mathrm{~F}$ \\
\hline 147 & Parmotrema nilgherrense (Nyl.) Hale & Par nil & & Fol & Cort & GA & 5 & $E, F, M$ \\
\hline 148 & Parmotrema praesorediosum (Nyl.) Hale & Par pra & & Fol & Cort & GA & 1 & M \\
\hline 149 & Parmotrema pseudocrinitum (Abbayes) Hale & Par pse & & Fol & Cort & GA & 1 & M \\
\hline 150 & Parmotrema pseudonilgherrense (Asahina) Hale & Par pse & & Fol & Cort & GA & 8 & $E, M, F$ \\
\hline 151 & Parmotrema reticulatum (Taylor) M. Choisy & Par ret & & Fol & Saxi & GA & 2 & C, E \\
\hline 152 & Parmotrema saccatilobum (Taylor) Hale & Par sac & & Fol & Cort & GA & 1 & E \\
\hline 153 & Parmotrema sancti-angelii (Lynge) Hale & Par san & & Fol & Saxi & GA & 1 & M \\
\hline 154 & Parmotrema subarnoldii (Abbayes) Hale & Par sub & & Fol & Saxi & GA & 2 & $C, M$ \\
\hline 155 & Parmotrema tinctorum (Despr. ex Nyl.) Hale & Partin & & Fol & Cort & GA & 1 & E \\
\hline 156 & Parmotrema ultralucens (Krog) Hale & Par ult & & Fol & Saxi & GA & 1 & M \\
\hline 157 & Peltigera didactyla (With.) J.R. Laundon & Pel did & \multirow[t]{7}{*}{ Peltigeraceae } & Fol & Musc & BGA & 1 & E \\
\hline 158 & Peltigera dolichorrhiza (Nyl.) Nyl. & Pel dol & & Fol & Cort & BGA & 3 & $\mathrm{~F}, \mathrm{E}$ \\
\hline 159 & Peltigera dolichospora (D.A. Lu) Vitik. & Pel dol & & Fol & Cort & BGA & 2 & $E, F$ \\
\hline 160 & Peltigera malacea (Ach.) Funck & Pel mal & & Fol & Musc & BGA & 1 & $\mathrm{~F}$ \\
\hline 161 & Peltigera membranacea (Ach.) Nyl. & Pel mem & & Fol & Musc & BGA & 2 & $\mathrm{~F}$ \\
\hline 162 & Peltigera polydactylon (Neck.) Hoffm. & Pel pol & & Fol & Musc & BGA & 3 & $E, F$ \\
\hline 163 & Peltigera praetextata (Flörke) Zopf & Pel pra & & Fol & Musc & BGA & 1 & C \\
\hline 164 & Pertusaria albescens (Huds.) M. Choisy \& Wern. & Per alb & \multirow[t]{14}{*}{ Pertusariaceae } & Cru & Cort & GA & 1 & E \\
\hline 165 & Pertusaria amara (Ach.) Nyl. & Per ama & & Cru & Cort & GA & 1 & $\mathrm{~F}$ \\
\hline 166 & Pertusaria amarescens Nyl. & Per ama & & Cru & Saxi & GA & 2 & $M, E$ \\
\hline 167 & Pertusaria commutata Müll. Arg. & Per com & & Cru & Saxi & GA & 1 & E \\
\hline 168 & Pertusaria composita Zahlbr. & Per com & & Cru & Cort & GA & 1 & M \\
\hline 169 & Pertusaria hemisphaerica (Flörke) Erichsen & Per hem & & Cru & Cort & GA & 1 & $\mathrm{~F}$ \\
\hline 170 & $\begin{array}{l}\text { Pertusaria krogiae A.W. Archer, Elix, Eb. Fisch., Killmann \& } \\
\text { Sérus }\end{array}$ & Per kro & & Cru & Cort & GA & 1 & E \\
\hline 171 & Pertusaria lactea (L.) Arnold & Per lac & & Cru & Cort & GA & 1 & $\mathrm{~F}$ \\
\hline 172 & Pertusaria ophthalmiza (Nyl) Nyl. & Per oph & & Cru & Cort & GA & 1 & $\mathrm{~F}$ \\
\hline 173 & Pertusaria pertusa (Weigel) Tuck. & Per per & & Cru & Cort & GA & 2 & $E, F$ \\
\hline 174 & Pertusaria psoromica A.W. Archer \& Elix & Per pso & & Cru & Cort & GA & 2 & $M, F$ \\
\hline 175 & Pertusaria umbricola A.W.Archer \& Elix & Per umb & & Cru & Cort & GA & 2 & E \\
\hline 176 & Pertusaria velata (Turner) Nyl. & Per vel & & Cru & Cort & GA & 1 & $\mathrm{~F}$ \\
\hline 177 & Pertusaria xanthoplaca Müll. Arg. & Per xan & & Cru & Cort & GA & 1 & E \\
\hline 178 & Phaeophyscia ciliata (Hoffm.) Moberg & Pha cil & \multirow[t]{5}{*}{ Physciaceae } & Fol & Cort & GA & 4 & $\mathrm{C}, \mathrm{E}$ \\
\hline 179 & Phaeophyscia endococcina (Körb.) Moberg & Pha end & & Fol & Saxi & GA & 2 & $M, C$ \\
\hline 180 & Phaeophyscia hispidula (Ach.) Moberg & Pha his & & Fol & Cort & GA & 1 & M \\
\hline 181 & Phaeophyscia hispidula var. exornatula (Zahlbr.) Moberg & Pha his & & Fol & Cort & GA & 2 & $\mathrm{~F}$ \\
\hline 182 & Phaeophyscia primaria (Poelt) Trass & Pha pri & & Fol & Saxi & GA & 1 & C \\
\hline 183 & Phaeographis extrusa (Stirt.) Zahlbr. & Phe ext & Graphidaceae & Cru & Cort & GA & 1 & $\mathrm{~F}$ \\
\hline 184 & Phlyctis argena (Ach.) Flot. & Phl arg & Phlyctidaceae & Cru & Cort & GA & 1 & $\mathrm{~F}$ \\
\hline 185 & Physcia caesia (Hoffm.) Fürnr. & Phy cae & \multirow[t]{4}{*}{ Physciaceae } & Fol & Saxi & GA & 3 & $M, C$ \\
\hline 186 & Physcia dilatata Nyl. & Phy dil & & Fol & Cort & GA & 1 & E \\
\hline 187 & Physcia semipinnata (Gmelin) Moberg & Phy sem & & Fol & Cort & GA & 1 & E \\
\hline 188 & Physcia tenella (Scop.) DC. & Phy ten & & Fol & Saxi & GA & 1 & M \\
\hline 189 & Platismatia erosa W. Culb. \& C. Culb. & Pla ero & Parmeliaceae & Fol & Cort & GA & 3 & $E, F, M$ \\
\hline 190 & Polychidium stipitatum Vězda \& W.A. Weber & Pol sti & Massalongiaceae & Fru & Cort & BGA & 1 & $\mathrm{~F}$ \\
\hline 191 & Porina chlorotica (Ach.) Müll.Arg. & Por chl & Porinaceae & Cru & Saxi & GA & 1 & $F$ \\
\hline 192 & Porpidia albocoerulescens (Wulfen) Hertel \& Knoph & Por alb & Lecideaceae & Cru & Saxi & GA & 1 & $\mathrm{~F}$ \\
\hline 193 & Pyxine berteriana (Fée) Imsh. & Pyx ber & Caliciaceae & Fol & Cort & GA & 2 & $\mathrm{~F}, \mathrm{E}$ \\
\hline 194 & Ramalina conduplicans Vain. & Ram con & \multirow{4}{*}{ Ramalinaceae } & Fru & Cort & GA & 8 & $F, E, M$ \\
\hline 195 & Ramalina hossei Vain. & Ram hos & & Fru & Cort & GA & 4 & $E, F, M$ \\
\hline 196 & Ramalina roesleri (Hochst) Hue & Ram roe & & Fru & Cort & GA & 3 & $M, F$ \\
\hline 197 & Ramalina sinensis Jatta & Ram sin & & Fru & Cort & GA & 1 & F \\
\hline 198 & Rhizocarpon badioatrum (Flörke ex Spreng.) Th. Fr. & Rhi bad & \multirow[t]{2}{*}{ Rhizocarpaceae } & Cru & Saxi & GA & 2 & $E, M$ \\
\hline 199 & Rhizocarpon obscuratum (Ach.) A. Massal. & Rhi obs & & Cru & Saxi & GA & 1 & M \\
\hline 200 & Rhizoplaca chrysoleuca (Sm.) Zopf & Rhi chr & Lecanoraceae & Fol & Saxi & GA & 2 & M \\
\hline 201 & Rinodina efflorescens Malme & Rin eff & \multirow[t]{4}{*}{ Physciaceae } & Cru & Cort & GA & 1 & M \\
\hline 202 & Rinodina instrusa (Krempelh. in Nyl.) Mamle & Rin ins & & Cru & Cort & GA & 2 & $M, E$ \\
\hline 203 & Rinodina lecideina H. Mayrhofer \& Poelt & Rin lec & & Cru & Saxi & GA & 1 & C \\
\hline 204 & Rinodina sophodes (Ach.) A. Massal. & Rin spo & & Cru & Saxi & GA & 1 & M \\
\hline 205 & Sclerophora amabilis (Tibell) Tibell & Scl ama & Coniocybaceae & Fru & Cort & GA & 1 & $\mathrm{~F}$ \\
\hline 206 & Stereocaulon paradoxum I.M. Lamb & Ste par & Stereocaulaceae & Fru & Saxi & GA & 7 & $M, E, C$ \\
\hline 207 & Stereocaulon piluliferum Th.Fr. & Ste pil & & Fru & Saxi & GA & 2 & C,E \\
\hline 208 & Sticta nylanderiana Zahlbr. & Sti nyl & Lobariaceae & Fru & Cort & GA & 2 & $F$ \\
\hline 209 & Sticta praetextata (Räsänen) D.D. Awasthi & Sti pra & & Fru & Cort & GA & 2 & $\mathrm{~F}, \mathrm{E}$ \\
\hline 210 & Sticta weigelii (Ach.) Vain. & Sti wei & & Fru & Cort & BGA & 1 & $\mathrm{~F}$ \\
\hline 211 & Sulcaria sulcata (Lév.) Bystr. ex Brodo \& D. Hawksw. & Sul sul & Parmeliaceae & Fru & Cort & GA & 2 & F, E \\
\hline 212 & Nephromopsis ahtii (Randl. \& Saag) Randl. \& Saag & Nep aht & & Fol & Cort & GA & 7 & $E, F$ \\
\hline 213 & Nephromopsis laureri (Kremp.) Kurok. & Nep lau & & Fol & Cort & GA & 5 & $F, E, M$ \\
\hline
\end{tabular}




\begin{tabular}{|c|c|c|c|c|c|c|c|c|}
\hline S.N. & Name of Lichen species & $\begin{array}{l}\text { Short } \\
\text { form }\end{array}$ & Family & $\begin{array}{l}\text { Growth } \\
\text { form }\end{array}$ & $\begin{array}{l}\text { Substrate } \\
\text { group }\end{array}$ & $\begin{array}{l}\text { Photobiont } \\
\text { partner }\end{array}$ & \begin{tabular}{|l|} 
Frequency \\
(Number)
\end{tabular} & $\begin{array}{l}\text { Land use } \\
\text { types }\end{array}$ \\
\hline 214 & Umbilicaria badia Frey & Umb bad & \multirow[t]{3}{*}{ Umbilicariaceae } & Fol & Saxi & GA & 4 & C, E, \\
\hline 215 & Umbilicaria indica var. indica Frey & Umb ind & & Fol & Saxi & GA & 8 & $F, M, E$ \\
\hline 216 & Umbilicaria vellea (L.) Ach. em. Frey & Umb vel & & Fol & Saxi & GA & 3 & $M, F$ \\
\hline 217 & Usnea bailey (Stirt.) Zahlbr. & Usn bai & \multirow[t]{9}{*}{ Parmeliaceae } & Fru & Cort & GA & 1 & E \\
\hline 218 & Usnea cirrosa Motyka & Usn cir & & Fru & Cort & GA & 8 & $E, F, M$ \\
\hline 219 & Usnea compressa Taylor & Usn com & & Fru & Cort & GA & 5 & $F, M, E$ \\
\hline 220 & Usnea cornuta Körb. & Usn cor & & Fru & Cort & GA & 4 & $E, M, F$ \\
\hline 221 & Usnea himalayana Bab. & Usn him & & Fru & Cort & GA & 2 & $E, F$ \\
\hline 222 & Usnea longissima Ach. & Usn lon & & Fru & Cort & GA & 3 & $\mathrm{~F}, \mathrm{E}$ \\
\hline 223 & Usnea pygmoidea (Asahina) Y. Ohmura & Usn pyg & & Fru & Cort & GA & 1 & $M$ \\
\hline 224 & Usnea spl Dill. ex Adans. & Usn spl & & Fru & Cort & GA & 3 & $M, E$ \\
\hline 225 & Usnea sp2 Dill. ex Adans. & Usn sp2 & & Fru & Cort & GA & 2 & $\mathrm{~F}, \mathrm{M}$ \\
\hline 226 & Verrucaria nigrescens Pers. & Ver nig & Verrucariaceae & Cru & Saxi & GA & 1 & C \\
\hline 227 & Xanthoparmelia tinctina (Maheu \& A. Gillet) Hale & Xan tin & Parmeliaceae & Fol & Cort & GA & 1 & $M$ \\
\hline 228 & Xanthoria fallax (Hepp) Arnold & Xan fal & \multirow[t]{2}{*}{ Teloschistaceae } & Fol & Cort & GA & 2 & $M, C$ \\
\hline 229 & Xanthoria parietina (L.) Th. Fr. & Xan par & & Fol & Cort & GA & 1 & $\mathrm{~F}$ \\
\hline
\end{tabular}

Appendix 2 - TukeyHSD test for multiple comparisons of mean species richness of lichens between land-use types and $b$. Biplot CCA scores.

a) TukeyHSD test for multiple comparisons of mean species richness of lichens between land-use types.

\begin{tabular}{|l|r|r|r|r|}
\hline Variables & Difference & Lower & Upper & p adjusted \\
\hline Exploited-Cultivated & 14.46 & 3.93 & 24.99 & 0.00 \\
\hline Natural-Cultivated & 12.33 & 2.05 & 22.60 & 0.01 \\
\hline Meadow-Cultivated & 9.90 & -0.62 & 20.43 & 0.07 \\
\hline Natural-Exploited & -2.13 & -12.09 & 7.82 & 0.94 \\
\hline Meadow-Exploited & -4.56 & -14.77 & 5.66 & 0.63 \\
\hline Meadow-Natural & -2.42 & -12.38 & 7.53 & 0.91 \\
\hline
\end{tabular}

b) Pearson correlations between environmental variables and CCA axes.

\begin{tabular}{|l|r|r|}
\hline Variables & \multicolumn{1}{|c|}{ CCA1 } & \multicolumn{1}{l|}{ CCA2 } \\
\hline Elevation & 0.964 & -0.184 \\
\hline Exploited forest & -0.005 & -0.178 \\
\hline Natural forest & -0.187 & -0.573 \\
\hline Meadow & 0.161 & 0.355 \\
\hline Canopy openness & 0.193 & 0.755 \\
\hline
\end{tabular}

Appendix 3 - Regression analysis results modelled for lichen species richness, growth forms, substrate types and photobiont types as response variables and canopy openness and elevation as predictor variables. The Quasi-Poisson family error fitted in GLM (Generalized Linear Model). p-values refer to linear (linear model) or quadratic (linear \& quadratic model) coefficient. p-value codes: 0 '***' 0.001 **' 0.01 '*' 0.05 ?'0.1. ns (non-significant) for $p>|0.1|$ which means marginal significance.

\begin{tabular}{|c|c|c|c|c|c|c|c|}
\hline Predictor variables & Response variables & Model & \begin{tabular}{|l|}
$\begin{array}{l}\text { Degrees of } \\
\text { freedom }\end{array}$ \\
\end{tabular} & $\begin{array}{l}\text { Residual } \\
\text { deviance }\end{array}$ & $\begin{array}{l}\text { Deviance } \\
\text { explained }\end{array}$ & $\Delta \mathrm{D}^{2}$ & $p(>\mid t$ value $\mid)$ \\
\hline \multirow[t]{21}{*}{ Canopy openness } & \multirow[t]{3}{*}{ Total lichen richness } & Intercept & 35 & 222.23 & & 0 & *** \\
\hline & & Linear & 34 & 199.19 & 23.04 & 0.104 & * \\
\hline & & Linear \& quadratic & 33 & 192.35 & 6.85 & 0.134 & ns \\
\hline & \multirow[t]{3}{*}{ Crustose species richness } & Intercept & 35 & 65.36 & & 0 & *** \\
\hline & & Linear & 34 & 58.56 & 6.80 & 0.104 & . \\
\hline & & Linear \& quadratic & 33 & 57.96 & 0.60 & 0.113 & ns \\
\hline & \multirow[t]{3}{*}{ Fruticose species richness } & Intercept & 35 & 111.10 & & 0 & $* * *$ \\
\hline & & Linear & 34 & 99.39 & 11.71 & 0.105 & * \\
\hline & & Linear \& quadratic & 33 & 90.94 & 8.45 & 0.18 & 0.09 \\
\hline & \multirow[t]{3}{*}{ Corticolous species richness } & Intercept & 35 & 289.78 & & 0 & *** \\
\hline & & Linear & 34 & 218.15 & 71.63 & 0.247 & $* *$ \\
\hline & & Linear \& quadratic & 33 & 204.48 & 13.67 & 0.294 & $\mathrm{~ns}$ \\
\hline & \multirow[t]{3}{*}{ Saxicolous species richness } & Intercept & 35 & 104.63 & & 0 & *** \\
\hline & & Linear & 34 & 79.87 & 24.76 & 0.23 & $* *$ \\
\hline & & Linear \& quadratic & 33 & 75.72 & 4.15 & 0.27 & $\mathrm{~ns}$ \\
\hline & \multirow[t]{3}{*}{ Cyanolichen species richness } & Intercept & 35 & 68.57 & & 0 & 0.37 \\
\hline & & Linear & 34 & 55.61 & 12.96 & 0.189 & * \\
\hline & & Linear \& quadratic & 33 & 54.72 & 0.89 & 0.202 & $\mathrm{~ns}$ \\
\hline & \multirow{3}{*}{$\begin{array}{l}\text { Green algal lichen species } \\
\text { richness }\end{array}$} & Intercept & 35 & 189.80 & & 0 & *** \\
\hline & & Linear & 34 & 174.93 & 14.87 & 0.078 & . \\
\hline & & Linear \& quadratic & 33 & 168.55 & 6.38 & 0.112 & $\mathrm{~ns}$ \\
\hline \multirow[t]{6}{*}{ Elevation } & \multirow[t]{3}{*}{ Total species richness } & Intercept & 35 & 222.23 & & 0 & *** \\
\hline & & Linear & 34 & 163.35 & 53.88 & 0.26 & $* *$ \\
\hline & & Linear \& quadratic & 33 & 160.42 & 2.93 & 0.28 & $\mathrm{~ns}$ \\
\hline & \multirow[t]{3}{*}{ Crustose species richness } & Intercept & 35 & 65.36 & & 0 & $* * *$ \\
\hline & & Linear & 34 & 56.24 & 9.12 & 0.14 & * \\
\hline & & Linear \& quadratic & 33 & 55.97 & 0.27 & 0.14 & $\mathrm{~ns}$ \\
\hline
\end{tabular}




\begin{tabular}{|c|c|c|c|c|c|c|c|}
\hline Predictor variables & Response variables & Model & \begin{tabular}{|l}
$\begin{array}{l}\text { Degrees of } \\
\text { freedom }\end{array}$ \\
\end{tabular} & \begin{tabular}{|l|} 
Residual \\
deviance
\end{tabular} & \begin{tabular}{|l|} 
Deviance \\
explained
\end{tabular} & $\Delta \mathrm{D}^{2}$ & $p(>\mid$ t value $\mid)$ \\
\hline \multirow[t]{15}{*}{ Elevation } & \multirow[t]{3}{*}{ Foliose species richness } & Intercept & 35 & 137.8 & & 0 & $* * *$ \\
\hline & & Linear & 34 & 104.81 & 32.99 & 0.24 & $* *$ \\
\hline & & Linear \& quadratic & 33 & 102.2 & 2.61 & 0.26 & ns \\
\hline & \multirow[t]{3}{*}{ Fruticose species richness } & Intercept & 35 & 111.10 & & 0 & *** \\
\hline & & Linear & 34 & 92.02 & 19.08 & 0.172 & * \\
\hline & & Linear \& quadratic & 33 & 91.65 & 0.37 & 0.152 & ns \\
\hline & \multirow[t]{3}{*}{ Corticolous species richness } & Intercept & 35 & 289.78 & & 0 & $* * *$ \\
\hline & & Linear & 34 & 235.08 & 54.7 & 0.189 & $* *$ \\
\hline & & Linear \& quadratic & 33 & 227.09 & 7.99 & 0.216 & ns \\
\hline & \multirow[t]{3}{*}{ Cyanolichen species richness } & Intercept & 35 & 68.57 & & 0 & 0.23 \\
\hline & & Linear & 34 & 59.13 & 9.44 & 0.138 & * \\
\hline & & Linear \& quadratic & 33 & 58.38 & 0.75 & 0.149 & $\mathrm{~ns}$ \\
\hline & \multirow{3}{*}{$\begin{array}{l}\text { Green algal lichen species } \\
\text { richness }\end{array}$} & Intercept & 35 & 189.80 & & 0 & $* * *$ \\
\hline & & Linear & 34 & 140.67 & 49.13 & 0.259 & $* *$ \\
\hline & & Linear \& quadratic & 33 & 138.19 & 2.48 & 0.272 & ns \\
\hline
\end{tabular}

Appendix 4 - Representative hemispherical photographs chosen from the analysed images characterizing transects in Ghunsa Valley, Kanchenjunga. $(1=2000 \mathrm{~m}, 2=2600 \mathrm{~m}, 3=3000 \mathrm{~m}, 4=3400 \mathrm{~m}$ and $5=3800 \mathrm{~m} ; \mathrm{E}=$ eastern slope, $W=$ western slope; $c=$ cultivated land, $e=$ exploited forest, $m=$ meadows and $f=$ natural forest).

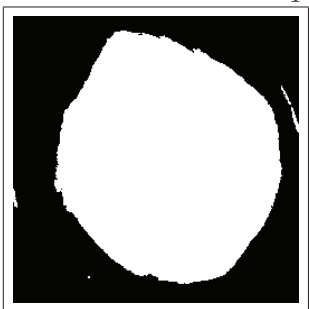

$1 \mathrm{Ecb}$

openness $=70.5 \%$

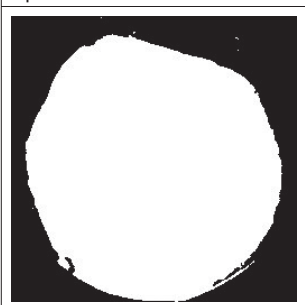

$1 \mathrm{Wcb}$

openness $=84.76 \%$

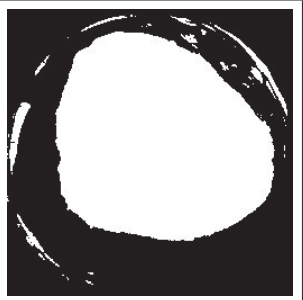

2Ecb 1

openness $=62.35 \%$

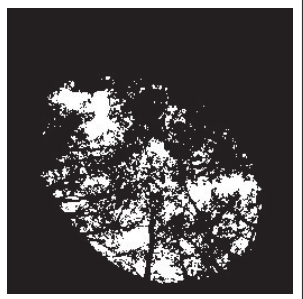

2Web

openness $=20.42 \%$

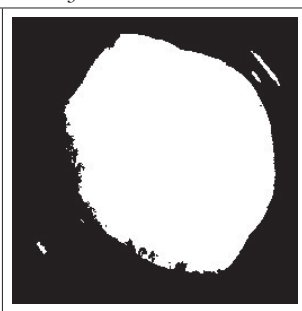

$1 \mathrm{Emb}$

openness $=62.4 \%$

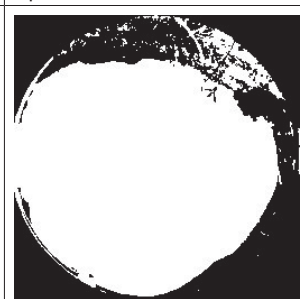

$1 \mathrm{Wmb}$

openness $=82.81 \%$

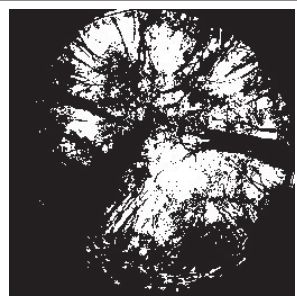

$2 \mathrm{Efb}$

openness $=31.48 \%$

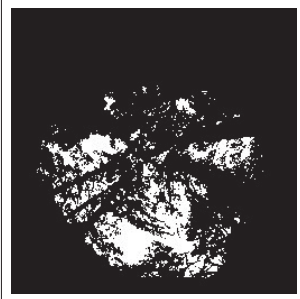

$2 \mathrm{Wfb}$

openness $=16.48 \%$

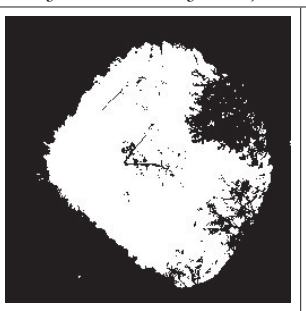

1Eea 1 Efb

openness $=55.75 \%$

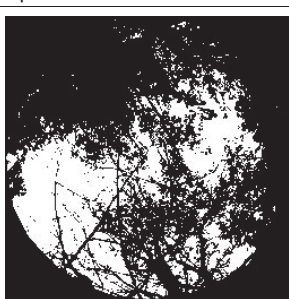

1 Web

openness $=37.05 \%$

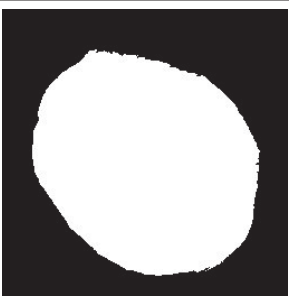

$2 \mathrm{Wcb}$

openness $=65.46 \%$

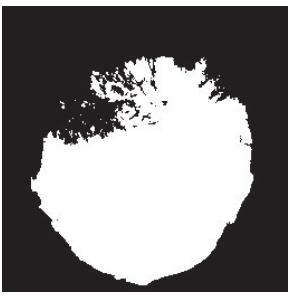

3Emc

openness $=55.92 \%$

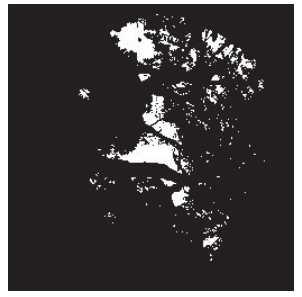

enness $=9.98 \%$

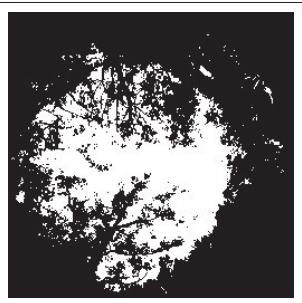

1Wfb2

openness $=38.46 \%$

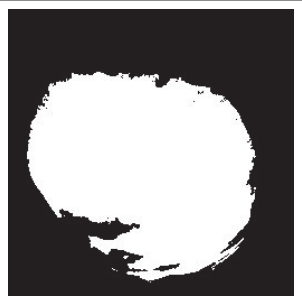

$2 \mathrm{Wmb}$

openness $=58.33 \%$

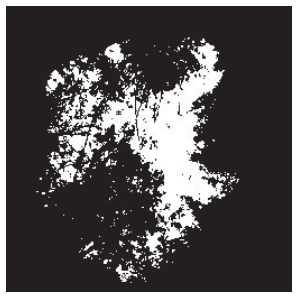

3Eeb

openness $=24.23 \%$ 


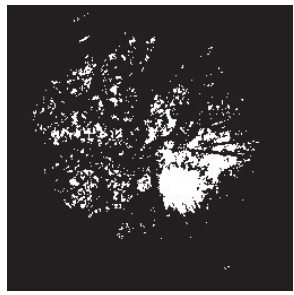

3Efb

openness $=14.06 \%$

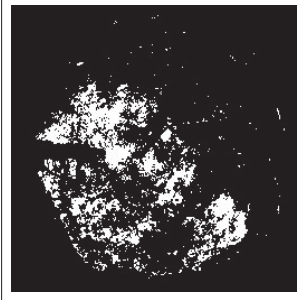

$3 W f b$

openness $=17.19 \%$

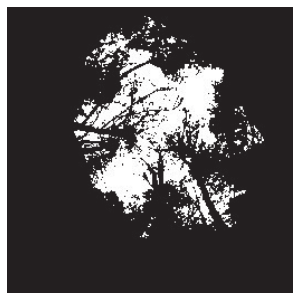

$4 \mathrm{Efb}$

openness $=21.51 \%$

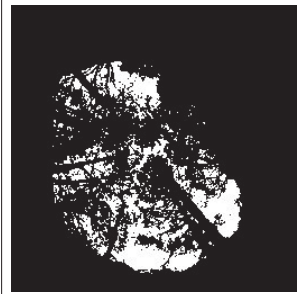

$4 \mathrm{Wfb} 1$

openness $=17.51 \%$

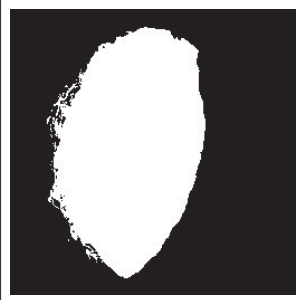

$5 \mathrm{Wcb}$

openness $=47.85 \%$

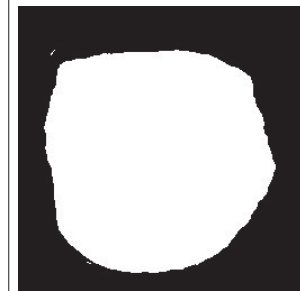

$3 \mathrm{Wcb}$

openness $=69.39 \%$

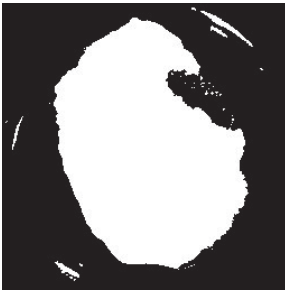

$4 \mathrm{Ecb}$

openness $=55.98 \%$

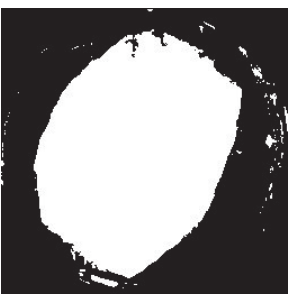

$4 \mathrm{Wcb}$

openness $=61.36 \%$

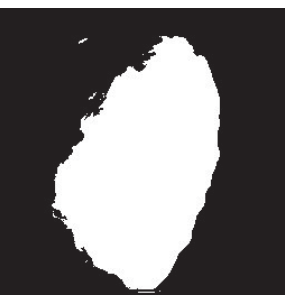

$5 \mathrm{Emb}$

openness $=47.72 \%$

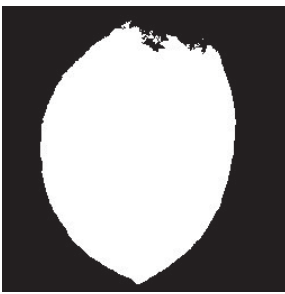

$5 \mathrm{Wmb}$

openness $=62.88 \%$

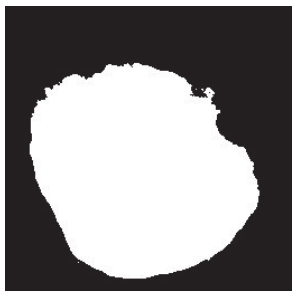

$3 \mathrm{Wmb}$

openness $=61.24 \%$

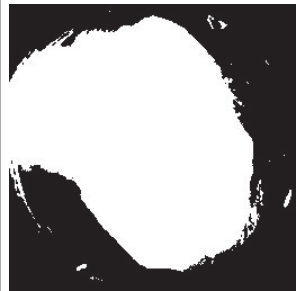

$4 \mathrm{Emb}$

openness $=7.16 \%$

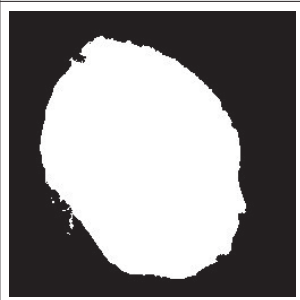

$4 \mathrm{Wmb}$

openness $=61.04 \%$

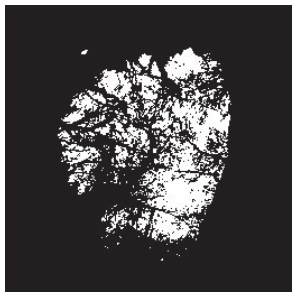

5Eeb

openness $=21.05 \%$

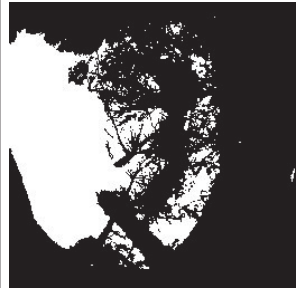

$5 \mathrm{Wec}$

openness $=35.16 \%$

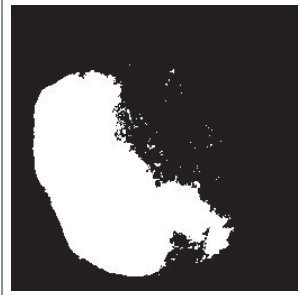

3 Web

openness $=36.53 \%$

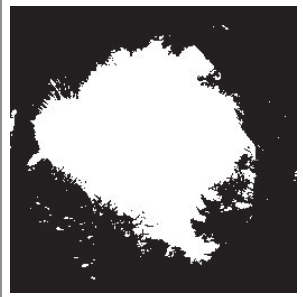

4Eeb

openness $=50.71 \%$

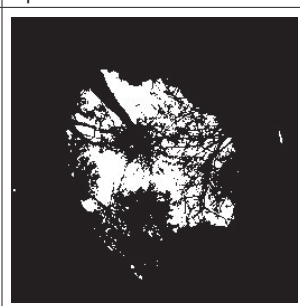

4 Wee

openness $=18.34 \%$

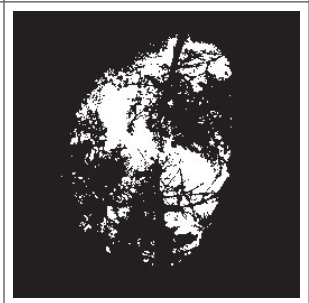

$5 \mathrm{Efb}$

openness $=19.78 \%$

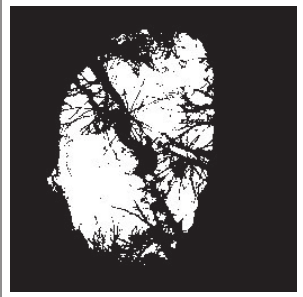

$5 \mathrm{Wfc}$

openness $=31.24 \%$ 